\title{
Long-term degradation, damage and fracture in deep rock tunnels: A review on the effect of excavation methods
}

\author{
Wadslin Frenelus, Hui Peng, Jingyu Zhang \\ Department of Hydraulic Engineering, College of Hydraulic and Environmental Engineering, China Three Gorges University, \\ Yichang 443002, China \\ wadslin@ctgu.edu.cn, bttps:/ / orcid.org/0000-0002-9084-2548 \\ 406955991@qq.com,304428211@qq.com
}

\begin{abstract}
Rocks are frequently host materials for underground structures, particularly for deep Tunnels. Their behavior plays a fundamental role in the overall stability of these structures. In fact, the erection of deep tunnels imposes rocks excavations around the defined routes. These excavations are generally carried out by various methods of which the most used are Drilland-Blast (DB) and Tunnel Boring Machine (TBM). However, regardless of the tunnelling method used, the impacts such as the perturbation of the initial stress field in rocks and the release of the stored energy are always significant. The impacts produce damage, fractures and deformations which are generally time-dependent and influence the long-term stability of deep tunnels built in rocks. Thus, by considering the aforementioned excavation methods, this paper identifies, reviews and describes the relevant factors generated during and after rock excavations. Interestingly, such factors directly or indirectly influence the long-term stability and therefore the structural integrity of deep rock tunnels. In addition, some recommendations and proposals for future works are presented. This paper can provide useful references in understanding the degradations, damage and fractures generated by tunnelling methods and facilitate suitable actions to ensure long-term stability of deep underground structures.
\end{abstract}

KEYWORDS. Excavation methods; Excavation impacts; Rocks behavior; Deep Tunnels; Structural Integrity; Long-term Stability.

\section{OPEN ACCESS}

Citation: Frenelus, W., Peng, H., Zhang, J., Long-Term Degradation, Damage and Fracture in Deep Rock Tunnels: A review on the effects of Excavation Methods, Frattura ed Integrità Strutturale, 58 (2021) 128-150.

Received: 13.05 .2021

Accepted: 03.08 .2021

Published: 01.10.2021

Copyright: (c) 2021 This is an open access article under the terms of the CC-BY 4.0, which permits unrestricted use, distribution, and reproduction in any medium, provided the original author and source are credited.

\section{INTRODUCTION}

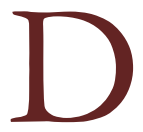

espite many challenges generally encountered in underground excavations, engineering projects for the construction of deep tunnels continue to grow. Indeed, the underground space needs are necessary from day to day particularly in developed countries. It is thereby widely known that deep tunnels can be built for various purposes such as water conveyance, reservoirs emptying, hydropower stations, sanitary drainage, etc. As a result, the longterm stability of these tunnels must be guaranteed, so that they can perform their roles correctly throughout their period of operation. However, this long-term stability is influenced by many potential factors, including the methods used to excavate these tunnels. 
It is quite obvious that, when excavating deep rocks tunnels, the virgin rock mass properties are modified [1, 2], and there are disturbances or alteration of the existing stresses in the rock massifs [3, 4]. There is then an imbalance in the stresses state of rocks which mainly surround the generated openings. For that, a new state of stress equilibrium is inevitable to prevent any early collapse of the excavations. It greatly depends on geological and geotechnical characteristics of the rocks and also on the excavation methods used. According to Kaiser et al. [5], stress changes strongly influence the stability of underground projects. Their impacts could be even more considerable when tunnels are constructed at great depth and when the lithology is variable. For instance, long deep tunnels generally cross heterogeneous rocky environments. So, one of the main challenges to be faced is the lack of information on geological structures of the areas to be excavated [6]. This would therefore entail a risk during tunnelling. The risks globally provoked by the tunnelling methods are numerous, both on the quality of rocks and on their properties. Rocks instability caused by excavations affect the overall safety and even sometimes the feasibility or the continuation of deep underground projects. Barton [7] has showed that the hybrid solution of TBM and DB methods can reduce risk in long deep tunnels. On their side, based on microseismic monitoring technology, Tang et al. [8] revealed that the speed balancing of TBM can attenuate the risk of surrounding rocks instability during excavations. But anyway, tunnelling by TBM and DB led to the creation of impacted zones in which there are generally permanent modifications of rocks properties in the vicinity of deep tunnels.

The aim of this paper is to describe the stages reflecting the influences of excavation methods on the long-term stability of deep tunnels built in rocky mediums. In fact, many studies have been carried out on the stability of underground structures, but attention has not been drawn sufficiently to the influence of tunnelling methods on long-term stability of deep tunnels. To address this issue, this review is presented in order to highlight the relevant factors generated during and after tunnels excavations. Each of these factors influence directly or indirectly the lifetime of tunnels. Their adequate consideration could constitute a source of ideas that could lead to the development of solutions to minimize their impacts on long-term stability of tunnels. It should be noted that the excavation operations of deep long tunnels can take years. In addition, due to stress factors, the strength of natural rocks is time-dependent [9]. The longer the excavations last, the greater the risk of deterioration of rocks properties due to the time effect. Accordingly, the more the tunnels created are unstable. Thus, study the influence of excavation methods on long-term stability of deep rocks tunnels is of tremendous importance.

\section{GENERAL ROCKS EXCAVATIONS METHODS OVERVIEW}

7 he main methods for rocks excavations are Drill-and-Blast (DB), and Tunnel Boring Machine (TBM) [10, 11]. The process of rocks removal is very different in the two mentioned tunnelling methods. In DB method, there are holes creation using long drill, and blasting the holes previously filled with explosives; while in TBM, the work is done thanks to the digging force of the machine equipped with rolling cutters operating at high pressure [12]. Tabs. 1 and 2 summarize the relevant advantages and disadvantages of the main tunnelling methods.

\begin{tabular}{|c|c|c|c|}
\hline $\begin{array}{l}\text { Excavation } \\
\text { method }\end{array}$ & General Relevant Advantages & General Relevant Disadvantages & Authors (year) \\
\hline \multirow{4}{*}{ DB } & $\begin{array}{l}\text { Good progression rate for } \\
\text { tunnels of small diameters. }\end{array}$ & $\begin{array}{l}\text { Low advancing rate for tunnels of } \\
\text { big diameter. }\end{array}$ & $\begin{array}{l}\text { Suorineni et al. (2008) } \\
{[13]}\end{array}$ \\
\hline & & $\begin{array}{l}\text { Generate crack fracture morphology. } \\
\text { High degree of damage in } \\
\text { surrounding rocks. Larger relaxation } \\
\text { depth. Impose usually considerable } \\
\text { strengthening measures. }\end{array}$ & Ji et al. (2012) [11] \\
\hline & $\begin{array}{l}\text { Comprehensive flexibility and } \\
\text { strong adaptability for many } \\
\text { geological conditions. }\end{array}$ & $\begin{array}{l}\text { Complex tunnelling procedures. } \\
\text { Considerable disturbances to } \\
\text { surrounding rocks. Rough excavation } \\
\text { perimeter. Slow progression rate. }\end{array}$ & Huang et al. (2018) [14] \\
\hline & Possible use for all types of rocks & $\begin{array}{c}\text { Blast damage are unavoidable and } \\
\text { persist }\end{array}$ & Zareifard (2020) [15] \\
\hline
\end{tabular}

Table 1: Relevant Advantages and Disadvantages of DB excavations 


\begin{tabular}{|c|c|c|c|}
\hline $\begin{array}{l}\text { Excavation } \\
\text { method }\end{array}$ & General Relevant Advantages & General Relevant Disadvantages & Authors (year) \\
\hline \multirow{5}{*}{ TBM } & $\begin{array}{l}\text { Fastest advancing rates in good ground } \\
\text { conditions. Tunnel route quite straight. }\end{array}$ & $\begin{array}{l}\text { Complex operation for complex } \\
\text { tunnelling geometry. Not too } \\
\text { applicable for short Tunnels. Low } \\
\text { steering capacity }\end{array}$ & $\begin{array}{l}\text { Suorineni et al. (2008) } \\
\text { [13] }\end{array}$ \\
\hline & & Inflexibility & $\begin{array}{l}\text { Yan et al. (2012) [10]; } \\
\text { Mazaira and Konicek } \\
\quad \text { (2015) [16] }\end{array}$ \\
\hline & $\begin{array}{l}\text { Favourable to the surrounding rocks } \\
\text { stability control. Construction efficiency. } \\
\text { Favourable for environmental } \\
\text { protection. High progression rate, } \\
\text { depending on in-situ stress intensity. }\end{array}$ & $\begin{array}{l}\text { Low adaptability to geological } \\
\text { conditions. Possibility of trapping } \\
\text { due to possible accidents and } \\
\text { geohazards. }\end{array}$ & Huang et al. (2018) [14] \\
\hline & Smaller relaxation depth & $\begin{array}{l}\text { Generate shear fracture } \\
\text { morphology. Existence of a certain } \\
\text { degree of damage for surrounding } \\
\text { rocks. }\end{array}$ & Ji et al. (2012) [11] \\
\hline & Progression rate considerable & Applicable for slope $\leq 10.5 \%\left(6^{\circ}\right)$ & Ma et al. (2020) [17] \\
\hline
\end{tabular}

Table 2: Relevant Advantages and Disadvantages of TMB excavations

Rock mass excavation, as pointed out by Bao et al. [18], affects strongly the safety and the stability of tunnels. Referring to Liu et al. [19], it is assumed that tunnels shall be severely damaged when deformations induced by the excavations exceed established tolerable limits. Hence, for ensuring the long-term stability of deep tunnels, proper measurements of deformations caused by excavations are extremely important.

\section{DEGRADATION OF PROPERTIES OF SURROUNDING ROCKS}

$\mathrm{T}$ unnel excavation is regarded as an unloading process that can cause degradation of the main properties of surrounding rocks. More broadly, Qiu et al. [20] and Niu et al. [21] have reported that the surrounding rocks endure a complex unloading-loading process during deep tunnelling. This process affects the main properties of rocks, and generates instability around tunnels. Cai and Kaiser [22] related that there is alteration of mechanical, hydraulic and geochemical properties of surrounding rocks when excavating underground openings. In their research, based on unloading effect, Luo et al. [23] studied the deterioration of the mechanical properties of surrounding rocks for deep tunnels and have found that the main mechanical properties (cohesion, internal friction angle, elastic modulus, and Poisson's ratio) exhibit nonlinear degradation features. Rocks strength around tunnels is reduced due to the degradation of their properties. The degradation of rocks properties is an unfavourable indicator for the long-term stability of tunnels.

Any excavation method (DB, TBM) generates degradations in the rocks surrounding the openings. Although the degree of rocks degradation varies depending on the excavation method used, in all cases the rock properties remain altered in the vicinity of the tunnels.

The extent of degradations generated by tunnelling on relevant rocks properties needs to be deeply investigated. This would help to elucidate in depth the influence of excavation methods on long-term stability of deep tunnels constructed in rocky environments.

\section{ExCAVATION Loose Zone AND ExCAVATION Disturbed Zone}

7 he zones that directly influence the service life of deep tunnels are mainly the Excavation Loose Zone (ELZ), also called Excavation Damaged Zone (EDZ), and the Excavation Disturbed Zone (EdZ) (see Figs. 1 \& 2). They play a key role in the understanding of the long-term stability of these structures. In the ELZ (EDZ), the physical, 
mechanical, hydraulic and geochemical properties of rocks are considerably degraded [24, 25, 26]. Consequently, in these zones, there is irreversibility of deformations. The ELZ or EDZ could also be called failed zone, referring to Eberhardt et al. [27], where slabbing failure can occur. It should also be noted that in EDZ, according to Verma et al. [28], not only there is degradation of the main properties of rocks, but there is also an increase in transferability properties. That is, in EDZ, transmissibility or transferability properties of rocks are augmented due to the degradations that could engender cracks and fractures. The evolution of EDZ (ELZ) strongly influence the stability of surrounding rocks around deep tunnels. Factors favorable to the formation and growth of EDZ must be identified and controlled. According to Yang et al. [29, 30], three main aspects may contribute to the formation of EDZ namely in-situ stress or excavation process, time-dependent behavior of rocks, and rock mass quality or evolution of fractured zones in rock mass. In fact, the EDZ is particularly formed when concentrated compressive or tensile in-situ stress is higher than the rock strength [31,32,33]. Under geostress environment, referring to Yang et al. [30], EDZ can provoke at the same time cracks growth and stress redistribution around tunnels. It also facilitate the flow of groundwater inside deep tunnels, increasing the risk of instability of said structures [34]. The extent of EDZ depends on several factors, but mainly on the excavation method used. It could be thicker in Drill-and-Blast tunnelling than TBM $[35,36]$.

The EdZ is the expansion of stress redistribution at some regions near the openings. In these zones, rocks are weakened [27]. In the EdZ, also called Excavation Influence Zone (EIZ), the hydromechanical and geochemical properties of rocks are not change considerably [35, 26]. For circular tunnels, according to Du et al. [37], the extent of EdZ depends on the tunnels radius and generally limited to 3 times of their radius $(\leq 3 \mathrm{R})$.

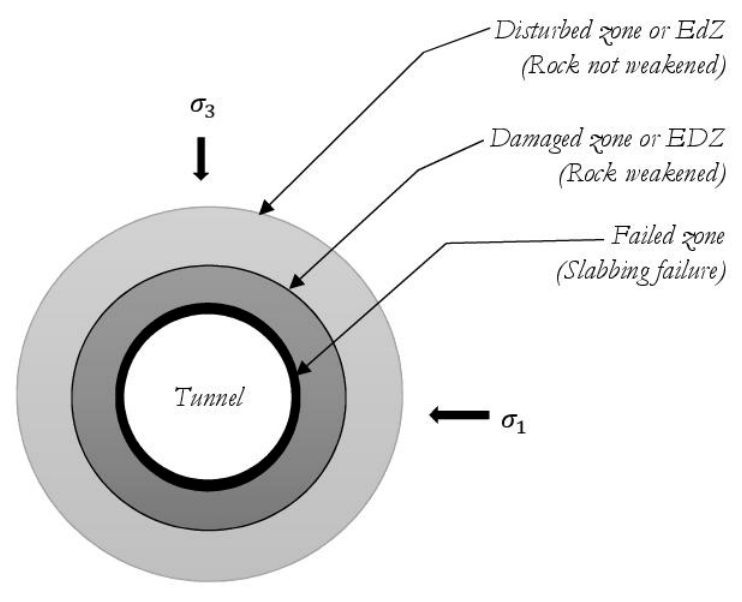

Figure 1: EDZ and EdZ surrounding a circular tunnel subjected to the stresses $\sigma_{1}$ and $\sigma_{3}$, adapted from Eberhardt et al. [27]

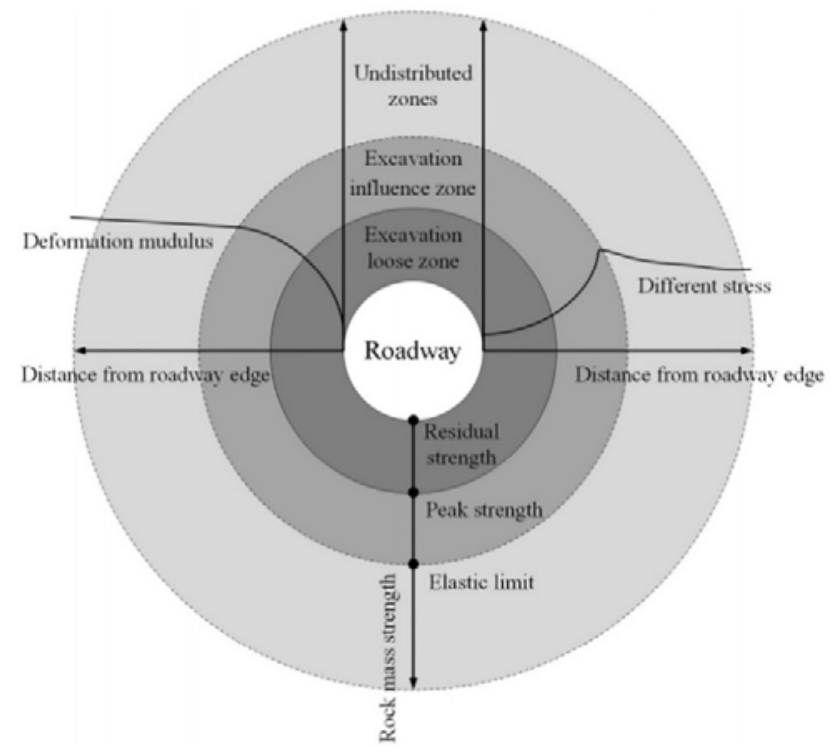

Figure 2: Diagram of failure zones during and after excavation. Reprinted from [26], Copyright 2019 Elsevier BV 
It is important to note that, as said by Perras and Diederichs [38], in in-situ measurements, the distinction between EIZ and EDZ is not obvious, and the transition between them is gradual. Their impacts on long-term stability of deep tunnels are significant. The extent evaluation of these zones must be taken into account since they can change with time [39, 40, 41, 18]. In addition, they influence considerably the stress field in roof region of tunnels [42]. The view of stress-strain curve (Fig. 3) can show the irreversibility of deformations in the EDZ by triaxial compression test.

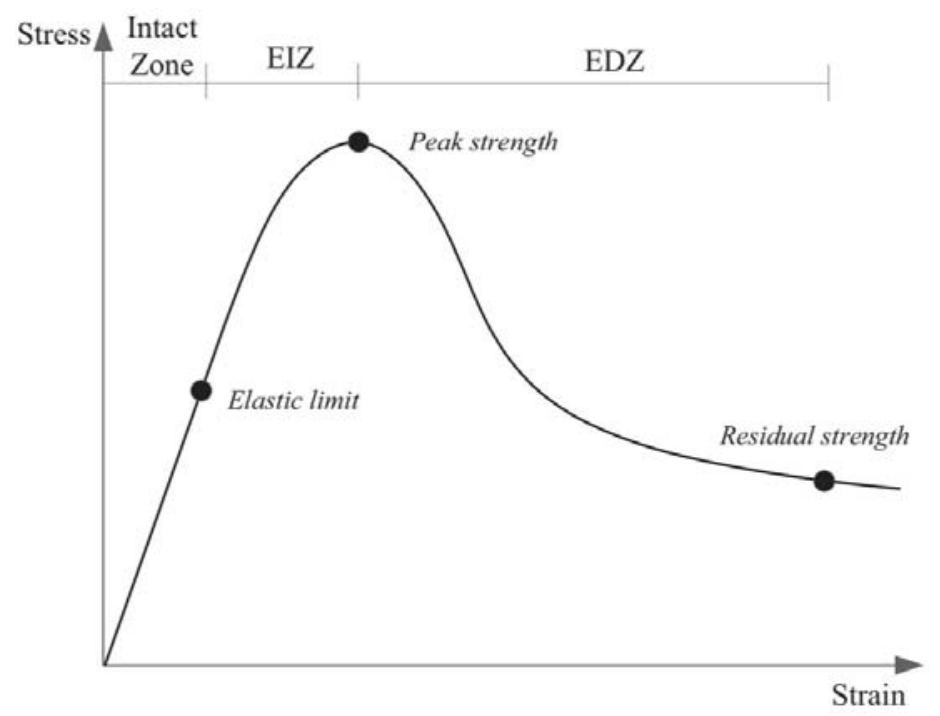

Figure 3: Stress-strain curve showing the location of EDZ and EIZ, adapted from [43] and [44], Copyright 2011 \& 2015 , Elsevier

As revealed by Kwon et al. [2], the characteristics of the EDZ are seriously influenced by the excavation method used. In fact, additional damage is generated by any excavation method. However, there are more supplemental EDZ provoked by the DB method than that of TBM method. Regarding the EdZ or EIZ, the effects of excavations are habitually minor, as outlined by Satici and Topal [45], but exist nonetheless. Depending on the magnitude of the stress disturbances beyond the EDZ, the amplitude of EdZ may vary and become significant, and its effects may therefore become considerable. It should thus be recognized that both TBM and DB excavations increase the magnitude of EDZ and EdZ in the surrounding rocks of tunnels.

\section{ENERGY RELEASE DURING ROCKS EXCAVATIONS}

$\mathrm{D}$ uring rocks excavations, the stored energy is disturbed. These excavations can lead to the release of elastic strain energy suddenly $[46,47]$. The perturbations can induce serious damage and affect the stability of rocks located in the vicinity of deep tunnels. Based on the work of Yan et al. [10], Tab. 3 presents the characteristics of the relevant factors for the Energy release during DB and TBM tunnelling.

\begin{tabular}{ccc}
\hline Relevant Factors & DB & TBM \\
Behavior of the stress paths process & Transient unloading & Quasi-static unloading \\
Energy release magnitude & Larger & Smaller \\
Energy Release Extent & Higher & Lower \\
Energy Release Rate (ERR) & Higher & Lower \\
Energy Release Speed (ERS) & Higher & Lower \\
\hline
\end{tabular}

Table 3: Relevant factors of the Energy Release during DB and TB tunnelling. 
According to Yang et al. [29], the elastic stress energy depends on various factors such as principal stresses, number of elements contained in the rocks, and the mechanical properties of rocks. Rocks with more elements can release more strain energy.

The most significant damage is related to the higher releases of the elastic strain energy. The strain energy released in the rocks is extremely essential to understand the sudden structural failure of the rocks [48]. As shown in Tab. 3, the energy release by the unloading stress during $\mathrm{DB}$ excavations is transient and higher. The DB tunnelling may cause more perturbation and more degradation in the surrounding rocks of tunnels. Moreover, as reported by Fan et al. [49], the energy release during the transient unloading of the in-situ stress is not only highest, but also fastest. So, DB tunnelling can deteriorate the surrounding rocks of tunnels faster than the TBM excavations. However, the effects of both tunnelling methods are permanent in the EDZ.

\section{DAMAGE AND FAILURE}

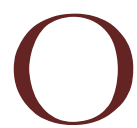

ne manner to take account of damage in a material is to use the concept of net stresses. As noted by Hoxha et al. [50], the "net stresses" concept is used to describe how damage influences the mechanical response of a damaged material. Lemaitre and Chaboche [51] have shown that, for a solid under a constant uniaxial tensile stress $(\sigma)$, the "net stress" $\left(\sigma^{*}\right)$, which depends on the damage factor $(D)$, is given by

$$
\sigma^{*}=\sigma /(1-D)
$$

Rocks damage can be associated with creep (see Fig. 4) which are both time-dependent phenomenon. According to Brantut et al. [52], during creep, the damage parameter can take values from 0 (intact) to 1 (broken) and can be expressed as follows:

$$
\sigma=E(1-\beta) \varepsilon
$$

where the applied stress is $\sigma$, the Young modulus is $E$, and the creep strain is $\varepsilon$. The constant $\beta$ is called damaged parameter. When rock is deformed by creep, the elastic modulus is decreased owing to damage [53, 54]. By equating $\beta=D$ , the last equation is

$$
\sigma=E(1-D) \varepsilon
$$

More broadly, rocks damage can also be expressed using the energy dissipation concept. Referring to Yang et al. [55], the global damage equation of rocks using the energy dissipation concept is as follows:

$$
\left\{\begin{array}{l}
D=0 \quad\left(U<U_{0}\right) \\
D=\frac{U-U_{0}}{\alpha U_{0}} \quad\left(U_{0} \leq U<(1+\alpha) U_{0}\right) \\
D=1 \quad\left(U \geq(1+\alpha) U_{0}\right)
\end{array}\right.
$$

$U_{0}$ is the critical strain energy corresponding to the initial damage; $U$ is the strain energy expressed by

$$
U=\int_{0}^{\varepsilon_{i j}} \sigma_{i j} d \varepsilon_{i j}
$$

where $\sigma_{i j}, \varepsilon_{i j}$ are stress tensor and strain tensor respectively, $(i j=1,2,3)$; The principal stresses are $\sigma_{1}, \sigma_{2}, \sigma_{3}$; For positive compression $\sigma_{1} \geq \sigma_{3}=\sigma_{2}$. The principal strains are $\varepsilon_{1}, \varepsilon_{2}, \varepsilon_{3} ; \alpha$ is a parameter related to the materials properties.

The relationship between Damage and Energy release can explain that greater Energy corresponds to greater Damage. In other words, the more energy the rocks release, the greater the damage is. In fact, great damage evolution lead to instability 
of structures, and can affect the bearing capacity of rocks. Mu et al. [56] have reported that the instability of structure is the macroscopic result of damage evolution and strength degradation in microstructures.

Damage and failure are closely linked. Any damage generates a form of structural instability which can lead to failure. Tang et al. [57] pointed out that the failure of rocks is caused by the damage evolution from initial defects. The latter, when they exist, are even more vulnerable during excavations. Accumulation or evolution of damage in structures always results in failure when they exceed their allowable limit. According to Jiang et al. [58], the time-dependent damage affects the major safety of surrounding rocks when it is severe. In fact, failure process in tunnels is composed by 3 stages (Fig. 5) including initiation, propagation and coalescence of cracks $[59,20]$. When it is completed, partial or total failure can occur in deep tunnels.

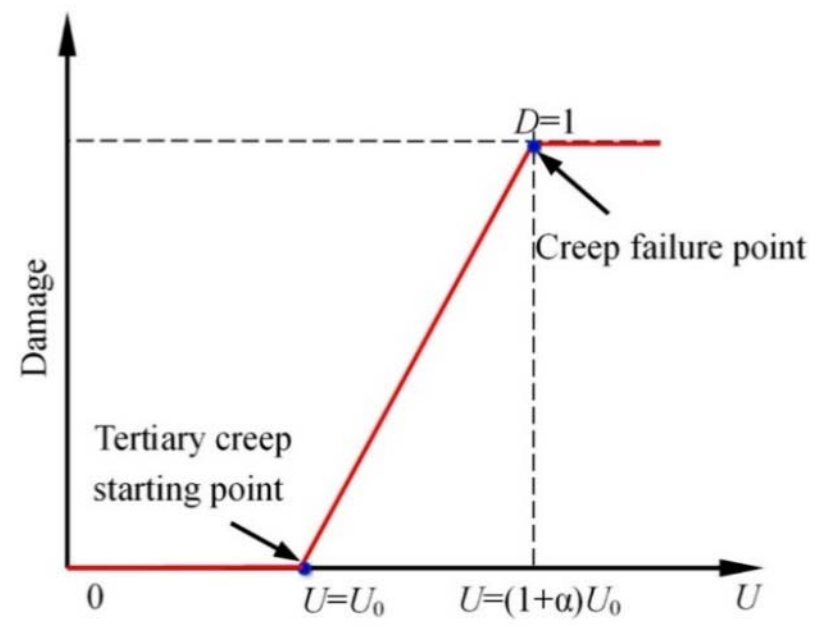

Figure 4: Rock damage evolution trend related to creep. Reprinted from [55], Copyright 2018 MDPI.

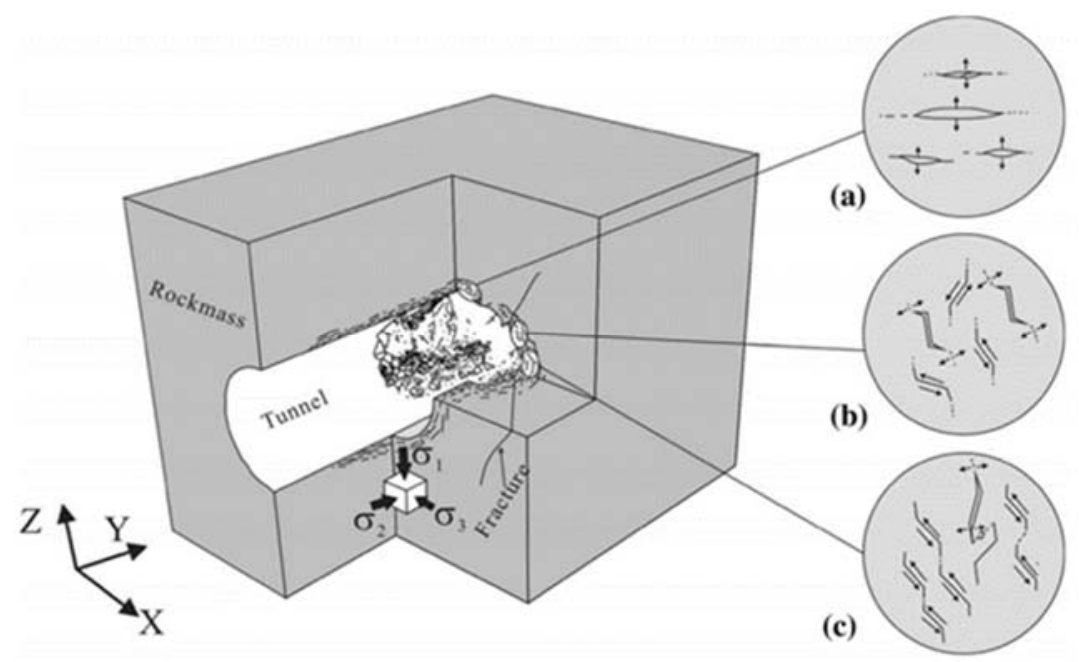

Figure 5: Illustration of excavation failure and damage evolution in deep rock tunnel; a): crack initiation and propagation in tension; b): crack initiation and propagation in shear; c) coalescence. Reprinted from [20], Copyright 2013 Springer-Verlag Wien.

Tunnels failure usually occurs by loss of rocks strength, or by excessive deformations or by serious damage of the support systems. Any type of failure mode can occur during and after excavations. When rocks are subjected to stress, fracture toughness and fracture energy are two important characteristics that must be taken into account. In fact, it should be noted that there is an energy consumption or dissipation during the initiation of cracks. The energy dissipation increases with the evolution of cracks [60]. Cracks and fractures evolution depends on fracture toughness of rocks. Fracture toughness of rocks is the resistance to cracks expansion [61, 62]. Fracture energy of rocks is the energy release rate which could be related to the disturbances generated by the excavation methods. More precisely, fracture energy refers to the energy required to cause fractures in rocks [62]. As related by Dong et al. [60], when the fracture energy is considerable up to its critical value, 
cracks can propagate in the surrounding rocks of tunnels. Toughness and fracture energy values can indicate how resistant rocks or structures are to the propagation of cracks or fractures. The most stable structures are those built with materials that have the highest fracture energies. Tunnels built in rocky environments with high fracture energies may have higher degree of integrity during and after excavations by TBM or DB. In plane strain condition, fracture energy and fracture toughness $\left(K_{I C}\right)$ and can be linked as follows [60]:

$$
G_{C}=K_{I C}^{2}\left(\frac{1-v^{2}}{E}\right)
$$

where $G_{C}$ is the critical fracture energy; $K_{I C}$ is the mode I fracture toughness; $v$ is the Poisson's ratio; $E$ is the elastic modulus.

Some quantitative values of the fracture toughness and fracture energy of rocks based on the performed tests conditions are summarized in Tabs. 4 and 5, in mode I. In fact, according to Kusch et al. [63], cracks can be propagated by mode I, II and III in loaded and stressed materials, but mode I is of paramount importance. Note that fracture toughness and fracture energy of rocks vary with different factors such as depth, geometry, temperature, confining pressures, etc.

\begin{tabular}{cccc}
\hline Rock type & $\begin{array}{c}\text { Fracture Toughness, } \\
K_{I C}(M P a \sqrt{m})\end{array}$ & Testing Method & Source (year) \\
Tage Tuff & $0.30-2.4$ & SCB and SENRBB & Funatsu et al. (2004) [64] \\
Schist & 2.70 & SENB & Momber (2015)[65] \\
Limestone & 1.21 & SENB & Momber (2015)[65] \\
Mudstone & $0.73-0.85$ & SCB & Yang et al. (2019) [66] \\
Andesite & $2.04 \pm 0.66$ & FBD & Zhang (2002) [68] \\
Granite & 1.65 & SECBD & Zhang (2002) [68] \\
Sandstone & 0.67 & BDT & Nezhad et al. (2018)[69] \\
Shale & $0.38-1.38$ & BDT & Ghouli et al. (2021) [70] \\
Marble & $1.11-1.36$ & SCB & \\
\hline
\end{tabular}

Table 4: Quantitative values of fracture toughness for certain types of rocks

\begin{tabular}{cccc}
\hline Rock type & $\begin{array}{c}\text { Fracture Energy, } G_{C} \text { (Mode I) } \\
\left(J / \mathrm{m}^{2}\right)\end{array}$ & $\begin{array}{c}\text { Testing Method } \\
\text { or type }\end{array}$ & Source (year) \\
Limestone & 50 & FEMDEM & Guo et al. (2017) [71] \\
Shale & 30 & FEMDEM & Guo et al. (2017) [71] \\
Andesite & $35-152$ & SR and DCB & Karpuz and Bozdag (1996) [72] \\
Granite & $28-56$ & SCB & Nejati el al. (2021) [73] \\
Sandstone & $2.4-13.9$ & CCCD & Zhang et al. (2021) [74] \\
Marble & $7.5-12.5$ & BDT & Feng et al. (2020) [75]
\end{tabular}

Table 5: Quantitative values of fracture energy for certain types of rocks

After the tunnelling, as already mentioned, the physical, mechanical and hydraulic properties of rocks are permanently damaged in the EDZ. The extent of these degradations evolves with the magnitude of EDZ. For instance, as experimented by Kwon et al.[2], the elastic modulus can reach a huge reduction of up to $56 \%$ due to stress redistribution from blasting 
effects. Toughness and fracture energy are usually greatly reduced when rocks are subjected to various dynamic loads of excavations. For example, by analyzing marble samples under dynamic three-point bending tests, Yu et al. [76] showed the drastic change in toughness and fracture energy which decrease to $65.27 \%$ and $76.23 \%$ respectively of their initial values. They demonstrated that the deterioration of these properties increases with the evolution of damage in rocks. It is important de remember that, tunnel excavations generate dynamic perturbations in the surrounding rocks [20]. It should therefore be understood that the greater the damage generated by the excavations, the greater the risk of degradation of rock properties. Thereby, more cracks and fractures can be spread in the surrounding rocks of tunnels. This increasingly increases the degree of damage to rocks and the risk of tunnel failure.

\section{ROCKBURSTS}

$\mathrm{R}$ ockbursts are considered as frequent form of damage or disaster that can occur during excavations of deep tunnels. They are caused by excavation when unloading the in-situ stress $[77,78]$. Their risk is considerable during and after underground excavations. It increases when there is more elastic energy stored in the elastic zone, and less dissipated in the plastic zone [79, 80]. In fact, rockbursts are related to the strain energy that exists in the surrounding rocks of tunnels [81]. They can thus crop up when there is the highest release of that energy. In deep excavations, rockbursts are dangerous phenomenon mainly generated by the brittle failure of rocks related with induced seismic events [79, 82]. Although it remains a challenge particularly at great depth, rockbursts control and assessment are extremely important in the analysis of the longterm stability for deep tunnels. Indeed, Wu et al. [83] reported that rockbursts can generate strong decrease in the stability of surrounding rocks.

Rockbursts impacts on the stability of structures vary with their intensity. Based on elastic energy index $\left(W_{e t}\right)$, Zhou et al. [84] classified rockbursts into 4 groups for hard rocks, namely None rockburst $\left(W_{e t}<2\right)$, Light rockburst $\left(2 \leq W_{\ell t}<5\right)$, Medium rockburst $\left(5 \leq W_{e t}<10\right)$, and Heavy rockburst $\left(W_{e t}>10\right)$. This classification corresponds respectively to minor rockburst, moderate rockburst, intensive rockburst and extreme rockburst, according to Xie et al. [85].

Fractures or damage of surrounding rocks during and after excavation could be closely related to the intensity of generated rockbursts. It is obvious that heavy rockbursts produce more damage and more fractures. Many studies have been conducted about rockbursts prediction. Li et al. [86] have realised a study permitting to predict rockbursts based on seismic techniques. One of their findings is that the excavation rate influence the frequency of rockbursts. This frequency is an important factor in the stability of surrounding rocks. Some previous studies explained that rockbursts frequency increase as the excavation depth increases. They established empirical formulas [87] permitting to calculate a critical depth from which rockbursts frequency can be estimated. Rockbursts can occur frequently when the excavation depth is greater than the established critical depth. On their side, based on Acoustic Emission and on field measurements, Cheng et al. [88] have found that rockbursts signals are closely related to the adjustment of rock stresses. Xue et al. [89] established a hierarchical evaluation system for rockbursts prediction based on a set of index and criterion. Recently, He et al. [90] explained that one of the Rockbursts method prevention, is to avoid high stress concentration areas as early as possible when selecting the tunnel route. Indeed, rockbursts prediction could be used for a better control of the rockburst-induced damage during excavations. Tab. 6 presents the key factors and conditions favorable for rockbursts occurrence.

\begin{tabular}{cc}
\hline Key factors and conditions favorable for Rockbursts occurrence & Authors - Year \\
Strain Energy Accumulation and Stress Concentration & Pu et al.- 2018 [91] \\
Rock heterogeneity, disturbance and Newly-fractured zones & Ma et al. - 2018 [92] \\
Stress regime influenced by the excavation unloading & Liu et al. - 2018 [93] \\
Adjustment of stress field and loading system & Manouchehrian \& Cai-2018 [94] \\
Hard and rigid rocks under high levels stress & Mazaira \& Konicek - 2015 [16] \\
High in-situ stress & Zhang et al. - 2014 [6] \\
In-situ stresses influenced by geological structure & Yan et al. - 2012 [10] \\
Critical depth and current tectonic stress field & Li et al. - 2007 \\
Environment for stress concentration and Strain Energy Accumulation & Wang and Park - 2001 [95] \\
\hline
\end{tabular}

Table 6: Key factors and conditions favorable for Rockburst occurrence 
To sum up, rockburst occurrence is linked to the stress and strength of surrounding rocks [96], and thus mainly depends on the excavation methods. When considering, for instance, the readjustment of stress or the unloading of the in-situ stress, they are also factors on which the occurrence of rockburst depends. Nevertheless, such factors depend on rock excavation methods. In fact, in deep underground spaces, the significance of the stress adjustment varies according to the rocks excavation methods. On another hand, the geological characteristics and conditions of rocks can also play a role in the rockburst occurrence. Here again, it's the excavation method used that can make this occurrence possible to any extent. When excavating deep rocks, the sudden and delayed occurrence of rockbursts is governed by the excavation methods [97]. Prompt rockbursts are typically generated during DB excavation method, while delayed rockbursts are mostly provoked by TBM excavations. Indeed, the in-situ stress is unloaded differently in the two excavation methods, as shown in Tab. 3. Taking as example the diversion tunnel of Jinping II hydropower station located at the southwestern of China, Xie et al. [85] demonstrated that in both tunnelling methods, minor and moderate rockburst can occur during excavations. Nevertheless, moderate rockbursts are predominantly frequent in DB excavations. Likewise, as also revealed by par Yan et al. [10], Intensive rockbursts occur mostly in DB tunnelling (Fig. 6). It is important to emphasise that under the effects of tunnelling methods, geological structures also influence the intensity and the frequency of rockbursts, as reported by Fan et al. [97].

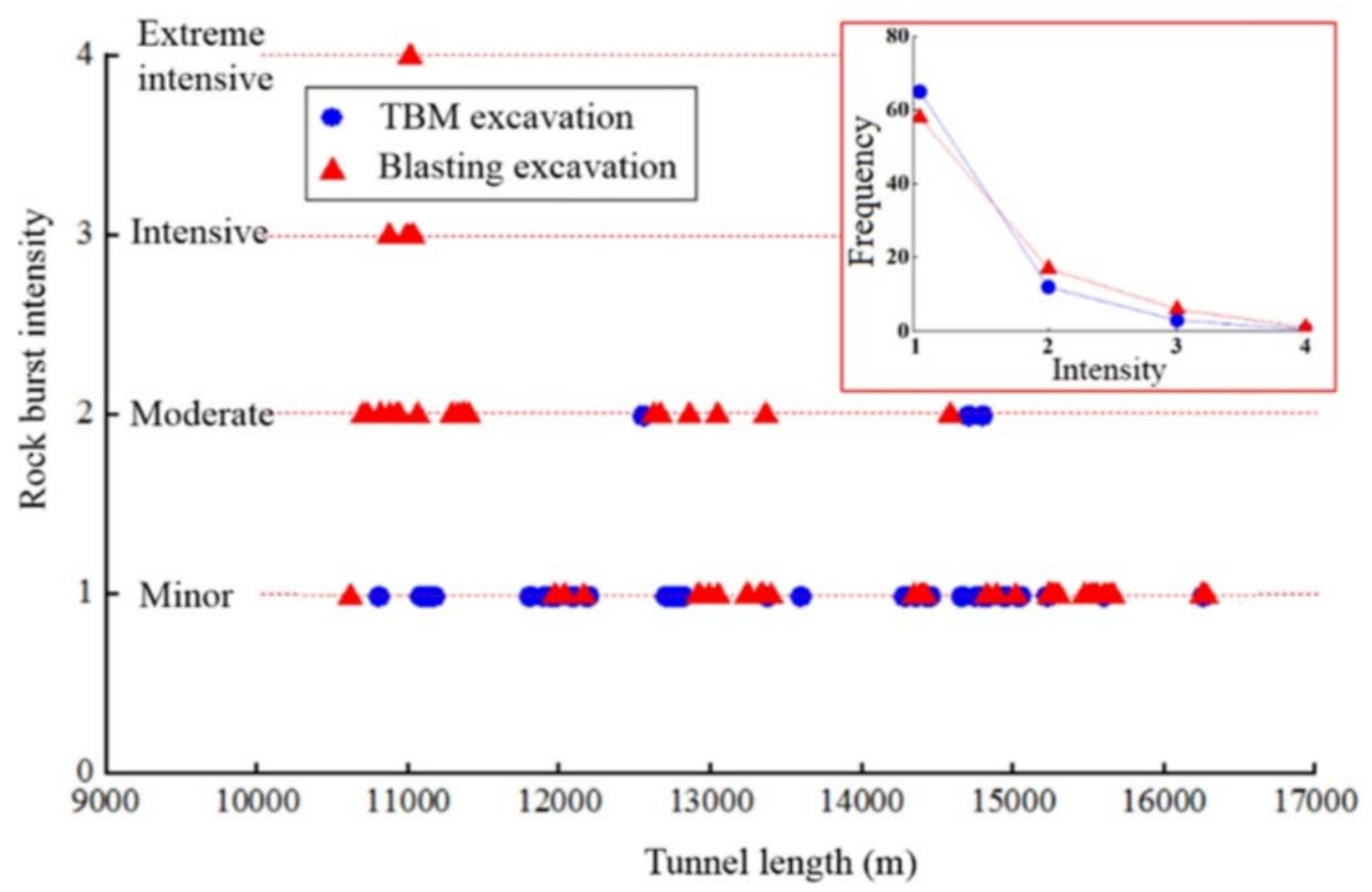

Figure 6: Rockbursts occurrence in rocks excavations by TBM and DB methods. Reprinted from [85], Copyright 2018 Springer.

Basically, the control of the energy release process in surrounding rocks during excavations is the best way to control rockbursts [98]. The greater the energy released, the larger the rockbursts and the greater the damage recorded in surrounding rocks. Thereby tunnels built in hard and brittle rocks executed by DB methods can generate a lot of rockbursts. This can increase damage and deformations of surrounding rocks and influence the long-term stability of deep Tunnels.

\section{CONSIDERATION ON ADVERSE GEOLOGICAL CONDITIONS}

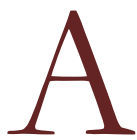

dverse geological conditions can affect the whole parameters of surrounding rocks during and after excavations, particularly when tunnelling by TBM. Therefore, a good knowledge of the geological conditions is strongly recommended prior to excavations, in order to foresee the necessary precautions. For ensuring adequate excavations, the main adverse geological should be known. Among these adverse geological conditions, we can mention: cavities, fractured and faults areas [99], high water inflow, spalling, squeezing and swelling ground [100]. They strongly 
influence the tunnelling and the long-term stability of deep tunnels. Huang et al. [14] reported that instability and collapse of the surrounding rocks are frequent when TBM excavations are done in zones with high fractures and faults. Active faults can cause partial or total collapse of tunnels. More specifically, some parts of tunnels can be collapsed when deformations produced by TBM excavation are enormous in faults areas [101]. As shown in Tabs. 1 and 2, one of the advantages of DB excavations is their great flexibility and adaptability in many geological conditions, while TBM are disadvantageous for unfavorable geological conditions. Such disadvantages of TBM must be seen both from a safety and an economic point of view. In fact, it is always reported by many Scholars and Researchers that there is high entrapment risk of TBM during excavations in adverse geological conditions. TBM entrapment generally cause serious excavations delays, and increase considerably the instability risk of tunnels and economic losses. Referring to Zhang et al. [6], due to unfavorable geological conditions, the TBM excavating the Yacambú-Quíbor deep tunnel in Venezuela was blocked and it took several years to remove its remains. In Taiwan, it took 15 years to complete the Syueshan tunnel. These examples can illustrate the complexity associated with tunnelling in adverse geological conditions. In fact, under these conditions, the surrounding rocks parameters become even more weakened by any excavation method. Nonetheless, DB excavations could produce less instability in the tunnels under such conditions.

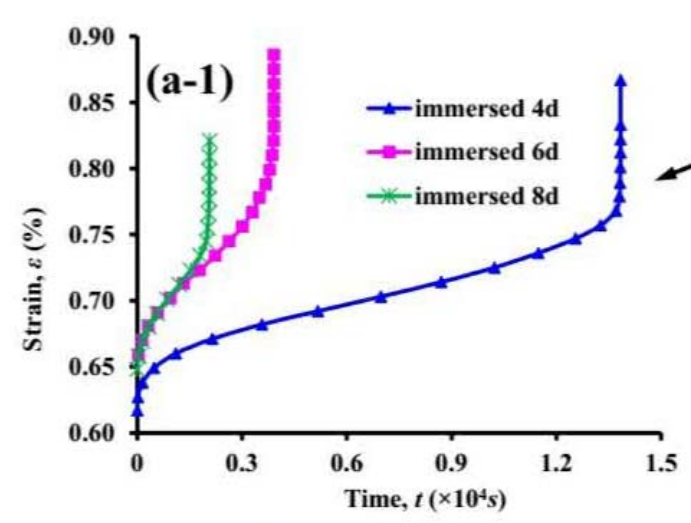

(a)
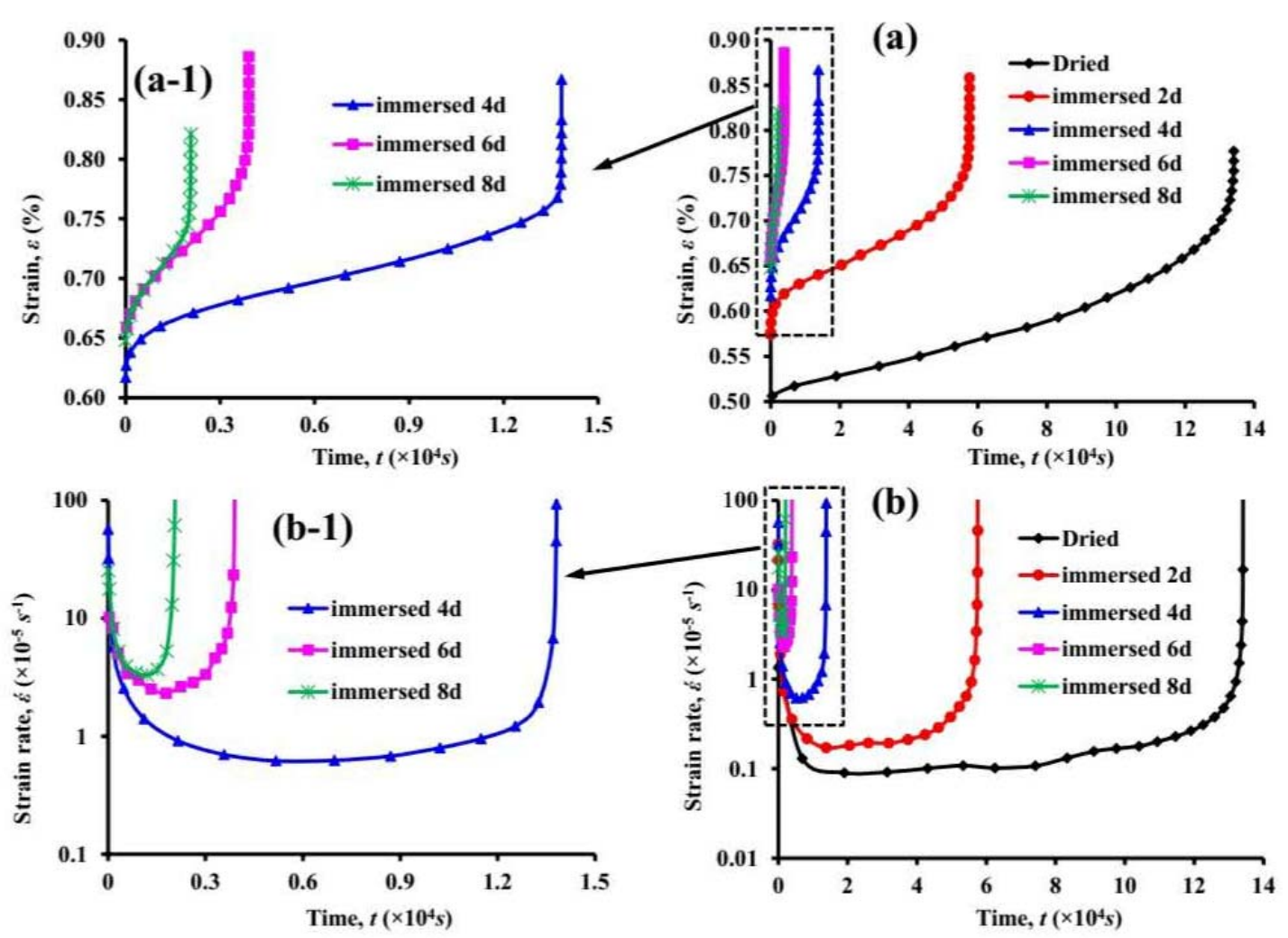

Figure 7: Illustration of the effects of water in rocks creep behavior. Figs. (a) and (b) show the creep behavior of red sandstones in dried state and in water soaked state at 2, 4, 6 and 8 days, at same stress conditions. The longer the rock samples are immersed, the shorter the lifetime is, and the faster the creep strain rate is. In dried state, the samples exhibit longer time-to-failure and the creep strain rate evolves slowly with time. The Figs. (a-1) and (b-1) in the left part are the zoomed-in view of the strain and strain rate curves for the rocks samples immersed in water at 4 days, 6 days and 8 days. Reprinted from [108], Copyright 2018 Springer-Verlag Austria

\section{CONSIDERATION ON HIGH GROUNDWATER PRESSURES AND FLOW}

A $\mathrm{t}$ great depth, high groundwater pressures can infiltrate into the excavated areas and attack the stability of surrounding rocks. According to Hoek [102] and Stille and Palmström [1], groundwater pressures generated overall instability and reduced rock strength and shear. Likewise, Liu et al. [103] reported that the unexpected groundwater inflow at tunnel head generate uncontrollable effects like for example mechanical instability and environmental impacts. 
The fight against heavy water pressure infiltration during tunnelling is frequent particularly for deep long tunnels, and requires much sustained attentions. In fact, as noted by Hwang and $\mathrm{Lu} \mathrm{[104]} \mathrm{and} \mathrm{Zhang} \mathrm{et} \mathrm{al.} \mathrm{[6],} \mathrm{one} \mathrm{of} \mathrm{the} \mathrm{challenges} \mathrm{to}$ be faced in deep tunnels is the high groundwater pressure. The problems induced by these inflows are usually assigned to water-rich fracture zones, particularly when using TBM [105]. Thereby, prediction and identification of high groundwater pressures must be done. Then, an adequate treatment is required to ensure tunnels stability. Referring to Zhang et al. [6] and Zhang et al. [106], some techniques (pre-excavation, decompression, blocking, and radial grouting) are generally used in order to fight against high-groundwater pressure around deep long tunnels. But the impacts of these pressures and water flows are not negligible in the long-term.

When studying the long-term stability of deep underground structures, emphasis should be placed on the creep behavior of their surrounding rocks. As pointed out by Zhou et al. [107], the long-term strength criterion can be considerably described by the creep failure of rocks. The time-dependent creep behavior of rocks is influenced by water and hydraulic pressures. Thus, taking into account the groundwater pressures and flows generated during excavations is important for a real evaluation of rocks creep strength. Fig. 7 illustrates uniaxial creep curves of red Sandstone samples studied by Tang et al. [108] in order to reveal the influence of water on creep behavior of this rock type. The red Sandstone samples was initially immersed in water at different durations like 2 days, 4 days, 6 days and 8 days. In the figure, the symbol "d" refers to days, the times are multiplied by $10^{4} s$, the creep strain rates are multiplied by $10^{-5} s^{-1} . s$ refers to second.

The literature reveals that the creep behavior of all types of rocks is significantly influenced by water. Tab. 7 presents the relevant effects of water on creep behavior for different types of rocks.

\begin{tabular}{|c|c|c|c|}
\hline Rock type & Effects of water on creep behavior of rocks & Testing Method & Reference (year) \\
\hline Tage tuff & Creep behavior of water-saturated Tage tuff is shortened & $\begin{array}{l}\text { Uniaxial compression } \\
\text { creep tests }\end{array}$ & $\begin{array}{l}\text { Okubo et al. } \\
(2010)[109]\end{array}$ \\
\hline Green-schist & $\begin{array}{l}\text { The increase in instantaneous axial and lateral strains is } \\
\text { caused by the increase of water content. }\end{array}$ & $\begin{array}{l}\text { Biaxial compression creep } \\
\text { tests }\end{array}$ & $\begin{array}{l}\text { Xiong (2014) } \\
\quad[110]\end{array}$ \\
\hline Limestone & $\begin{array}{l}\text { The increase in water and hydraulic pressure results in an } \\
\text { increase in creep strain and creep strain rate. }\end{array}$ & $\begin{array}{l}\text { Triaxial compression } \\
\text { creep tests }\end{array}$ & $\begin{array}{l}\text { Liu et al. (2015) } \\
\quad[111]\end{array}$ \\
\hline Mudstone & $\begin{array}{l}\text { The reduction in short-term mechanical properties and the } \\
\text { increase in both creep strain and creep strain rate are caused } \\
\text { by the presence of water. }\end{array}$ & $\begin{array}{l}\text { Uniaxial compression } \\
\text { tests and Multistage } \\
\text { Creep tests }\end{array}$ & $\begin{array}{l}\text { Lu and Wang } \\
(2017) \text { [112] }\end{array}$ \\
\hline Andesite & $\begin{array}{l}\text { The creep lifetime is drastically reduced by the presence of } \\
\text { water. It is about } 180 \text { times shorter in wet conditions than in } \\
\text { dry conditions, under the same stress conditions. }\end{array}$ & $\begin{array}{l}\text { Uniaxial compression } \\
\text { tests }\end{array}$ & $\begin{array}{l}\text { Hashiba et al. } \\
\text { (2018) [113] }\end{array}$ \\
\hline Shale & $\begin{array}{l}\text { With the presence of water, the mechanical behavior of Shale } \\
\text { is remarkably affected in Triaxial test. Under uniaxial tests, } \\
\text { there is reduction from } 58 \% \text { to } 62 \% \text { for the compressive } \\
\text { modulus and strength. The latter also decrease in } 36 \% \text { under } \\
\text { BDT. }\end{array}$ & $\begin{array}{l}\text { Uniaxial, Triaxial and } \\
\text { BDT Tests }\end{array}$ & $\begin{array}{l}\text { Li et al. (2020) } \\
\quad[114]\end{array}$ \\
\hline $\begin{array}{l}\text { Granite, Marble } \\
\text { and Sandstone }\end{array}$ & $\begin{array}{l}\text { Water considerably affects the mechanical characteristics of } \\
\text { rocks, and mainly decreases elastic modulus, critical strain } \\
\text { and uniaxial compressive strength. }\end{array}$ & $\begin{array}{l}\text { Uniaxial compression } \\
\text { tests ad Acoustic } \\
\text { Emission }\end{array}$ & $\begin{array}{l}\text { Cai et al. (2019) } \\
{[115]}\end{array}$ \\
\hline
\end{tabular}

Table 7: Effects of water on the Creep behavior of different types of rocks.

Indeed, groundwater pressures and flow generated by the tunnelling methods (DB and TBM) lead to an increase of water content in the surrounding rocks of tunnels. As shown in Fig. 7 and Tab. 7, the presence of water deteriorates the mechanical and creep properties of rocks. Accordingly, under the effect of excavation methods, water engenders long-term degradation in tunnels built in rocky environments. 


\section{CONVERGENCE DEFORMATION}

A $\mathrm{s}$ already mentioned, during and after excavations, the initial stress field always tries to stabilize by itself. As a result, rocks tend to closure around the openings. This closure is the deformation that called convergence of the rocks surrounding the tunnels. Convergence deformation is one of the severe effects of excavations which can be spectacular. It evolves as time increase owing to the time-dependent behavior of rocks [116, 4]. Convergence is inevitable, as revealed by Kontogianni et al. [117], since it is part of tunnels deformations mechanisms. According to them, due to the natural rocks behavior, tunnels convergence can be manifested in 3 stages: an accumulation rate, an evolution, and finally a stabilization. Furthermore, tunnel convergence can be limited to a distance less than twice the diameter of the openings. In other words, when an underground opening is created, the convergence deformation is naturally observable owing to the rocks behavior. However, the extent of such a deformation is influenced by the degree of rocks damage during and after excavations. In addition to the properties of rocks, any excavation method has impact on the tendency and extent of convergence. Paraskevopoulou and Diederichs [116] have showed that both tunnelling methods (DB and TBM) influence the convergence of tunnels. By considering an elasto-visco-elastic rock mass and the CVISC (visco-elastic-plastic) model, they numerically demonstrated that DB and TBM excavations effects increase the total displacement of rocks surrounding the tunnels. However, under similar duration of the excavation sequences, when rock mass conditions are favorable and tunnels length is considerable, TBM excavations can generate fewer additional displacements than that of DB. Otherwise, in adverse geological conditions, the additional wall displacements of tunnels are greater under TBM tunnelling.

Convergence is an essential factor in the study of tunnels stability. In fact, tunnel performance depends on it [118]. Consequently, tunnel convergence should be seriously controlled since the earlier stage of excavations, and throughout the lifetime of tunnels. As explained above, both tunneling methods influence the extent of tunnel convergence deformation by increasing it. The influence of excavation methods on tunnel convergence can be reduced if proper measures are taken as soon as possible. It is therefore extremely important to understand in depth such tunnel behavior and to adopt suitable solutions to limit it considerably. Tab. 8 presents an overview of the salient details in the study of convergence deformations for deep tunnels.

\begin{tabular}{|c|c|c|c|}
\hline $\begin{array}{l}\text { Type of rocks } \\
\text { or rock mass }\end{array}$ & $\begin{array}{l}\text { Convergence } \\
\text { measurement } \\
\text { method used }\end{array}$ & Salient findings & References (Year) \\
\hline All type & $\begin{array}{l}\text { Differentiation of } \\
\text { effects reflecting the } \\
\text { convergence }\end{array}$ & $\begin{array}{l}\text { Tunnels convergence describing by wall displacements depends on } \\
\text { the time-dependent behaviour of rocks and the face advance effect. }\end{array}$ & $\begin{array}{l}\text { Sulem et al. (1987) } \\
\text { [119] }\end{array}$ \\
\hline Sandstones & Fields monitoring & $\begin{array}{l}\text { In viscous media, there are relaxation path of rocks, and delayed } \\
\text { tunnels convergence. Consequently, tunnels convergence law is not } \\
\text { assimilated to the creep law. }\end{array}$ & $\begin{array}{l}\text { Pellet et al. (2000) } \\
\quad[120]\end{array}$ \\
\hline $\begin{array}{l}\text { Broken soft } \\
\text { rocks }\end{array}$ & $\begin{array}{l}\text { Multi-point } \\
\text { extensometers }\end{array}$ & $\begin{array}{c}\text { Floor heave represents } 65 \% \text { of the total roof and floor deformation. } \\
\text { There is huge deformation with rapid speed, and unevenly } \\
\text { distributed in the entire deep tunnel cross section. }\end{array}$ & $\begin{array}{l}\text { Wang Jin-xi et al. } \\
\quad(2009)[121]\end{array}$ \\
\hline $\begin{array}{l}\text { Soft rocks } \\
\text { under high } \\
\text { stress }\end{array}$ & Fields monitoring & $\begin{array}{l}\text { The average value of the convergence deformation in roof and floor } \\
\text { can at least double that of sidewalls. }\end{array}$ & $\begin{array}{l}\text { Yu et al. (2015) } \\
\quad[122]\end{array}$ \\
\hline $\begin{array}{l}\text { Deep buried } \\
\text { composite } \\
\text { rocks }\end{array}$ & $\begin{array}{l}\text { Finite element } \\
\text { difference \& similar } \\
\text { theory }\end{array}$ & $\begin{array}{c}\text { Surrounding rocks convergence deformations of tunnels are } \\
\text { composed in } 2 \text { parts: instantaneous and continuous creep } \\
\text { deformations. Soft rocks exhibit maximum convergence } \\
\text { deformations. }\end{array}$ & $\begin{array}{l}\text { Yang et al. (2019) } \\
{[123]}\end{array}$ \\
\hline Hard rocks & $\begin{array}{l}\text { Multi-point } \\
\text { extensometers }\end{array}$ & $\begin{array}{l}\text { Tunnel convergence could be divided in } 3 \text { stages: initial, rapid and } \\
\text { stable convergence. }\end{array}$ & $\begin{array}{l}\text { Wang et al. (2019) } \\
{[124]}\end{array}$ \\
\hline $\begin{array}{l}\text { Good rock } \\
\text { mass quality }\end{array}$ & $\begin{array}{l}\text { Advance borehole } \\
\text { monitoring \& } \\
\text { numerical inversion } \\
\quad \text { analysis }\end{array}$ & $\begin{array}{l}\text { Deformations characteristics of surrounding rocks are traduced by } \\
\text { the convergence deformations. The surrounding rocks crown } \\
\text { convergence deformation can be well analysed during tunnelling for } \\
\text { double-shield TBM tunnels. }\end{array}$ & $\begin{array}{l}\text { Li et al. }(2020) \\
\quad[125]\end{array}$ \\
\hline
\end{tabular}

Table 8: Salient details about Convergence deformations due to tunnelling 
Fig. 8 illustrates that the deformations wall-wall (which is assimilated to convergence) of tunnels increases with the increasing of time after the excavation period. This rheological behavior is strictly related to the rocks types and excavation methods. Huge rocks perturbations during excavations can involve huge convergences over time for deep tunnels.

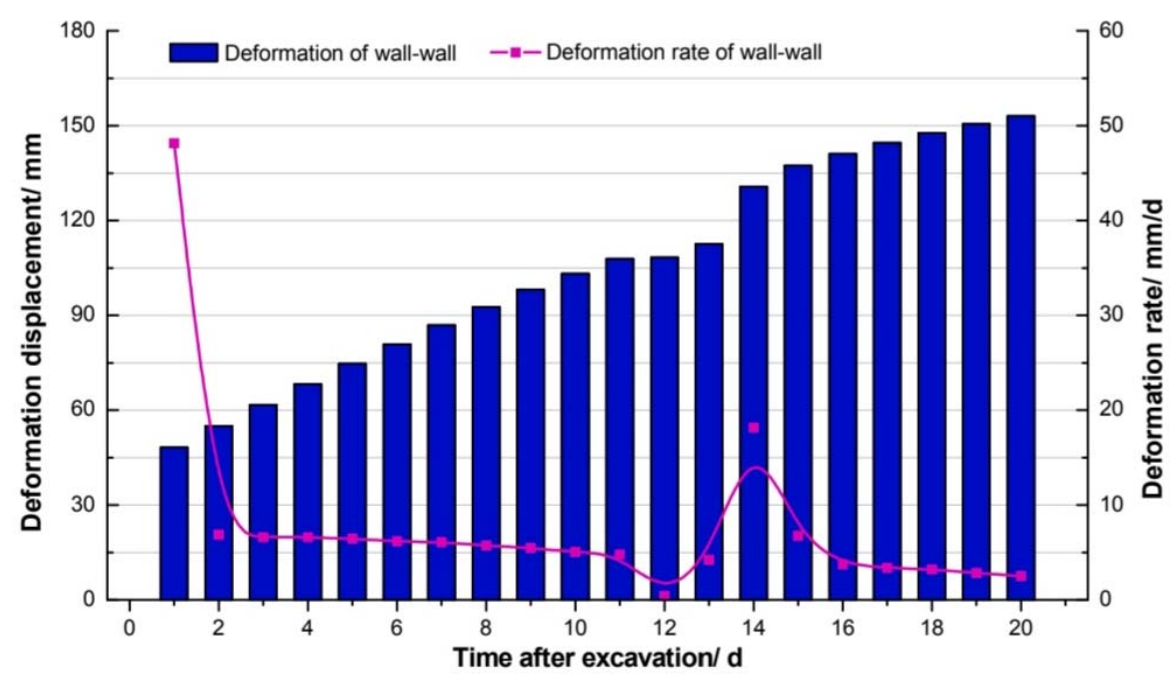

Figure 8: Illustration of the evolution of convergence deformations in tunnels. Reprinted from [56], Copyright 2020 Elsevier Ltd

\section{Discussion AND Propositions}

$\mathrm{T}$

he analysis of papers highlights different potential factors of excavations methods which impact the stability of deep tunnels. These factors evolve over time, and their influence on the above structures stability will be for long-

term. The extent of these influences depends firstly on the characteristics of the encountered rocks at the excavations depth and the geological conditions, and secondly on the excavations methods used. In fact, unfavourable geological conditions delay tunnelling [126], and consequently lead to additional impacts to the rocks around tunnels. For example, initially fractured rocks are generally more vulnerable to excavations and more damaged than that of unfractured. Zhang et al. [106], revealed that the damage generated by the fractures of rocks are frequent. When tunnelling in these rocks, damage would be added to the initial damage increasing the instability of deep underground structures.

Adverse effects exist in all tunnelling method. In order to design adequate tunnels supports and reduce the excavations impacts, adequate control and measurement of damage or deformations should be done. In fact, the duration of the excavation operation is an important factor. Some tunnels collapse during the period of their excavation [127]. The excavation time depends on several parameters including the geotechnical characteristics of rocks, the tunnelling methods as well the capacity and speed of work.

From an intact deep rock mass until the setup of support systems for deep tunnels, potential factors illustrating the influence of excavations methods are in the diagram hereinafter (Fig. 9).

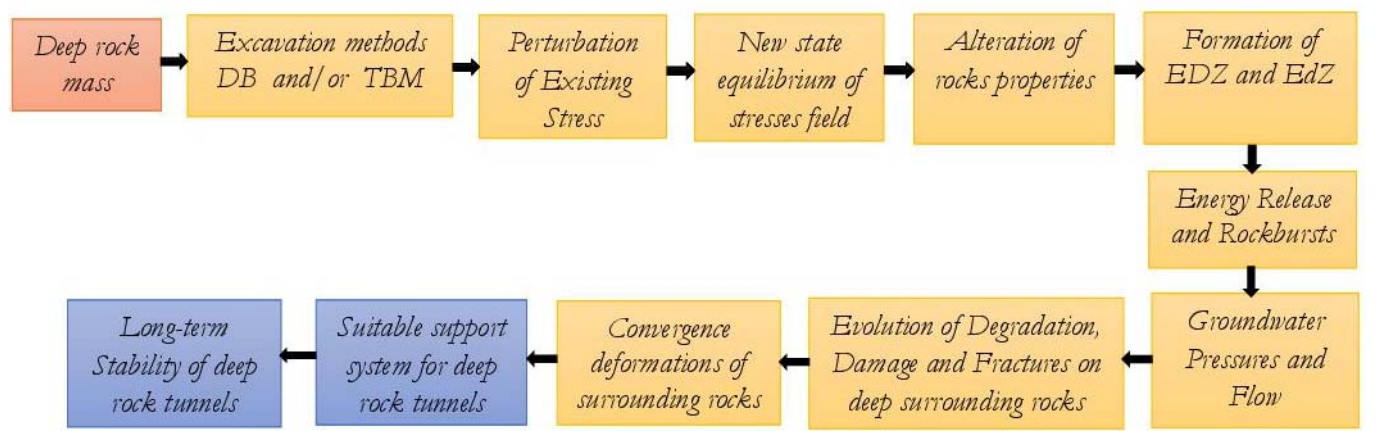

Figure 9: Diagram showing the influence of excavation methods on long-term stability of tunnels 
The lifespan of tunnels could be influenced by the manner in which the surrounding rocks have been disturbed, damaged and deformed during and after excavations. Indeed, the least durable tunnels could be those whose surrounding rocks were the most severely damaged and deformed during and after excavations. Considering a saturated viscoplastic rock mass by referring to Deleruyelle et al. [128], the life cycle of deep tunnels can be detailed in four stages such as Excavation, Tunnel unlined, Lining emplacement, and post-closure (Fig. 10). The post-closure stage is the total destruction of tunnels which mainly depends on the extent of convergence deformation accumulated in the first three stages, and over time.

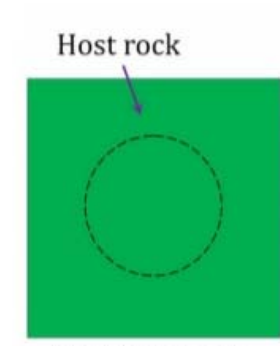

INITIAL STATE

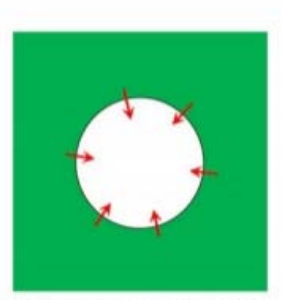

(2) UNLINED TUNNEL

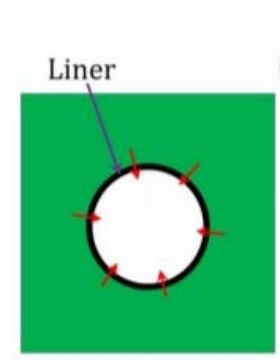

(3) OPERATION TIME

PRE-CLOSURE (SHORT TERM)

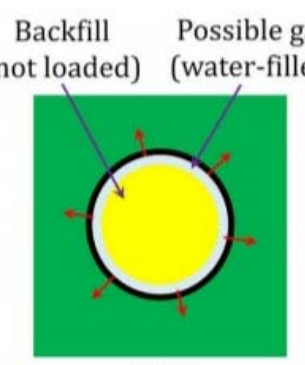

$(4 \mathrm{~A})$

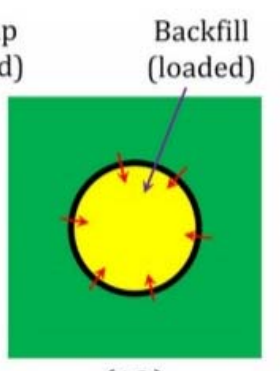

(4B)

(4) POST-CLOSURE

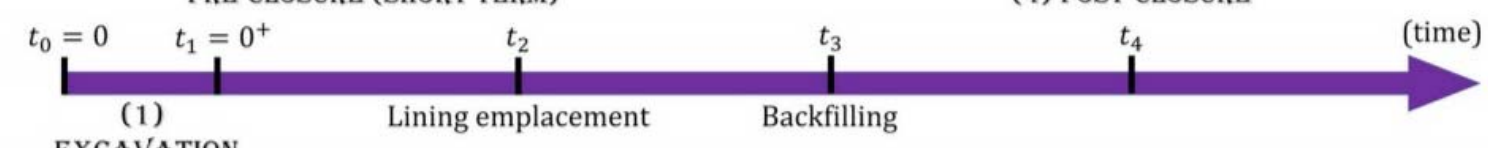

EXCAVATION

Figure 10: Illustration of tunnels life cycle. Reprinted from [128], Copyright 2016 Elsevier Masson SAS

In order to mitigate the influence of excavation methods in deep tunnels, the following steps are proposed: Firstly, a good evaluation of the geological and hydrogeological properties of the areas to be excavated is crucial. Secondly, an evaluation of the tunnelling methods to be used should always be made. Indeed, especially for deep long tunnels, combined actions of two tunnelling methods could be beneficial at certain levels, and unfavourable in some points. So a good assessment of their impacts are required prior to tunnelling. Thirdly, a good selection of excavation sequences and direction is extremely important for the surrounding rocks stability. It also plays a great role in the stability of different components of tunnels. Fourthly, field monitoring and measurements are necessary throughout the tunnelling periods, in order to control damage fractures and rockbursts signals. All cracks and deformations generated during the excavations periods of deep tunnels should be well identified and assessed and all actions should be optimized during and after tunnelling. This will limit damage evolution by putting in place suitable support systems as quickly as possible in order that tunnels be stable during their service life.

The aforementioned steps can be performed through different methodologies and instrumentations such as: fields monitoring and relevant surveys, relevant empirical and/or analytical formulas, adequate experimental tests and numerical methods. More precisely, steps 1 and 2 can be effectuated by in-situ measurements, experimental tests, as well as numerical methods. In fact, both experimental tests and numerical methods can be employed to determine the hydro-mechanical properties of rocks. To ensure reliability, in many cases, numerical results can be compared with experimental results. Referring to Wang et al. [129], we outline that Machine Learning Techniques can also be used to determine or predict mechanical properties of rocks. For the step 3, pertinent numerical methods can provide goods results regarding the excavations sequences and directions of deep rock tunnels. Step 4 can be performed using field measurements and relevant numerical methods. Note also that the support systems or linings can be calculated using appropriated empirical or analytical formulas and numerical methods.

Fig. 11 illustrates the steps in more detail.

\section{FUTURE RESEARCH NEEDS}

$\mathrm{T}$ he long-term stability of deep rocks tunnels built in rocky mediums must always be sought. Despite that many previous studies are conducted, there are still several areas of research which deserve further studies in order to support accurate predictions of deep tunnel's long-term stability. Although it remains as challenge tasks, it is of tremendous importance to accurately estimate: 
- The extent of degradations of the mechanical properties for surrounding rocks and its influence on long-term stability of deep tunnels.

- The overall magnitude of EDZ and its influence on long-term life of deep rocks tunnels based on unloading effect.

- How excavations methods influence the rocks bearing capacity of deep tunnels based on time-dependent effect.

- The total damage and deformations generated in the surrounding rocks after TBM and/or Drill-and-Blast excavations based on creep effect.

- Comparison of the convergence deformations magnitude between tunnels excavated by TBM and DB under same geological and hydrogeological conditions.

- Long-term Stability Analysis of deep tunnels based on post-excavation evaluation.

- The degradation of the fracture toughness and fracture energy in deep rocks tunnels after TBM and Dill-and-Blast excavations.

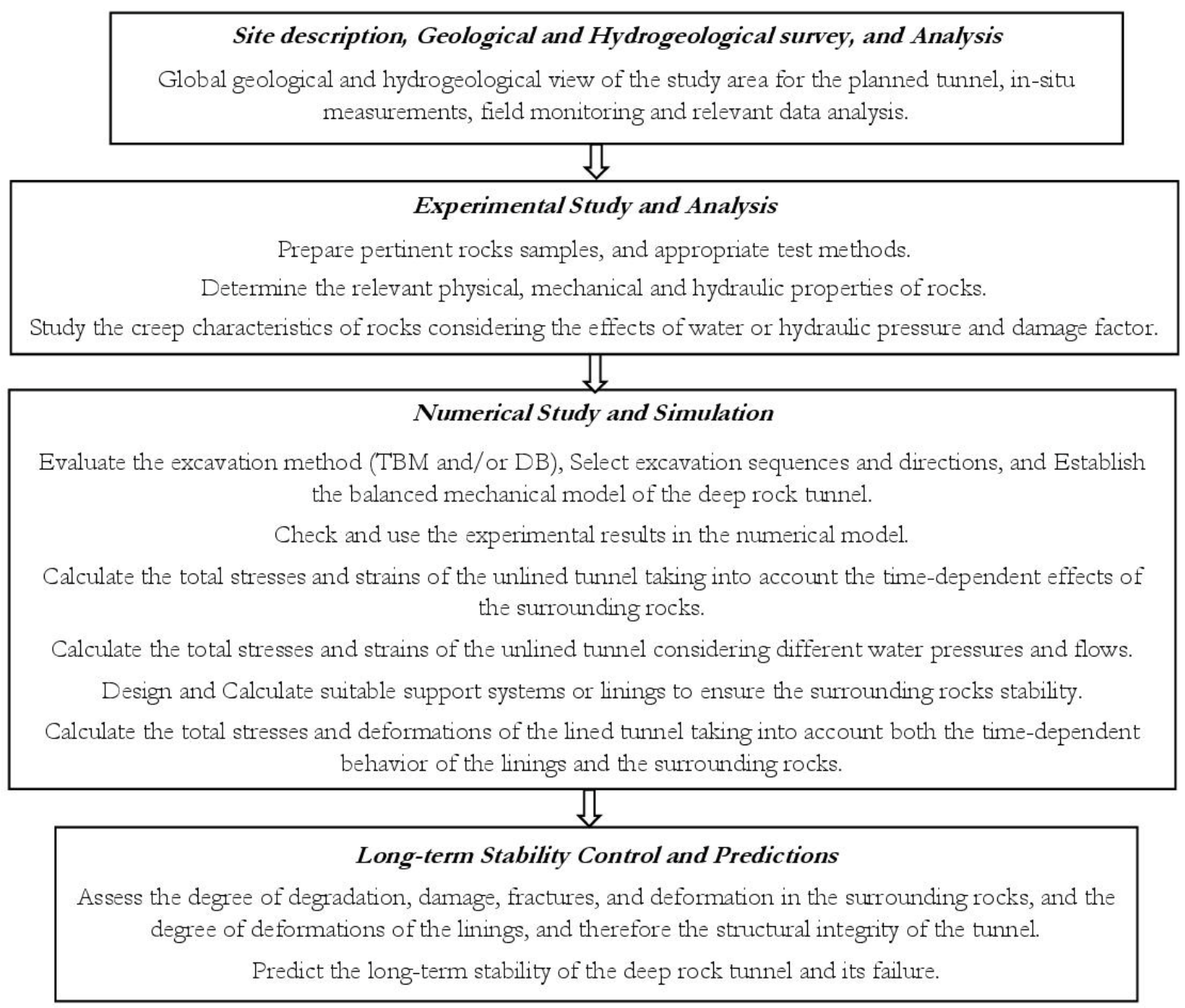

Figure 11: Proposed methodologies to control and mitigate the effects of excavations methods on the long-term stability of deep rocks tunnels.

\section{CONCLUSIONS}

7 he excavations methods have considerable influence on long-term stability of deep rock tunnels. The main conclusions related to this paper are summarized as follows: 
a) The long-term stability of deep tunnels is influenced by the long-term stability of its surrounding rocks. Any excavation method has adverse effects on the properties of rocks, and impact the durability of deep rocks. Thereby it influences the long-term stability of deep tunnels owing to the degradation of the physical, mechanical, and hydraulic properties of the surrounding rocks.

b) Owing to the Energy release during excavations, Rockbursts are inevitable, especially during hard and brittle rocks excavations. In engineering practice, the tunnelling rate must well be controlled to prevent intensive rockbursts. The latter cause generally more damage and weaken much more the surrounding rocks of tunnels. Consequently the life time of these tunnels can be more impacted.

c) For deep long tunnels crossing complicated geological zones, when a combination of Drill-and-Blast and TBM methods is employed, high stress concentrations in the intersection areas will also influence the lifetime of deep tunnels.

d) The proper design of the lining systems depends on the conditions of surrounding rocks after excavations. Thus, the excavation methods used govern on the long-term the support systems of deep rock tunnels. The greater the damage or deformation, the more resistant the support systems must be.

e) After rocks excavations, deformations increase continuously and failure can occur over time due to the timedependent behavior of natural rocks. Hence, the total convergence deformation caused by the excavations should be predicted minutely considering all the relevant factors. Indeed, long-term monitoring is necessary during the lifetime of deep tunnels.

f) All tunnelling methods impose additional deformations on surrounding rocks of deep tunnels. These deformations can be minimized if actions are optimized during the tunneling period. However in any case they influence the tunnels long-term stability.

g) To ensure the long-term stability of deep rocks tunnels, a high degree of structural integrity is required.

\section{NOMENCLATURE}

$\begin{array}{ll}\text { DB: } & \text { Drill-and-Blast } \\ \text { TBM: } & \text { Tunnel Boring Machine } \\ \text { ELZ: } & \text { Excavation Loose Zone } \\ \text { EDZ: } & \text { Excavation Damaged Zone } \\ \text { EIZ: } & \text { Excavation Influence Zone } \\ \text { EdZ: } & \text { Excavation Disturbance Zone } \\ \text { ERR: } & \text { Energy Release Rate } \\ \text { ERS: } & \text { Energy Release Speed. } \\ \text { SCB: } & \text { Semi-circular bend } \\ \text { SENRBB: } & \text { Single edge-notched round bar in bending } \\ \text { SENB: } & \text { Single edge notch bend } \\ \text { FBD: } & \text { Flattened Brazilian Disc } \\ \text { SECBD: } & \text { Single Edge Cracked Brazilian Disk in diametric compression } \\ \text { BDT: } & \text { Brazilian Disk Test } \\ \text { FEMDEM: } & \text { Combined finite-discrete element method } \\ \text { SR: } & \text { Short rod } \\ \text { DCB: } & \text { Double Cantilever Beam } \\ \text { CCCD: } & \text { Center-Cracked Circular Disc } \\ \text { CVISC: } & \text { Visco-elastic-plastic or Burger Constitutive Viscoplastic. }\end{array}$

\section{ACKNOWLEDGEMENTS}

he work is supported by the China Scholarship Council (CSC No.2019GBJ008203). 


\section{REFERENCES}

[1] Stille, H., Palmström, A. (2008). Ground behaviour and rock mass composition in underground excavations. Tunnelling and Underground Space Technology, 23 (1), pp. 46-64. DOI: 10.1016/j.tust.2006.11.005

[2] Kwon, S., Lee, C., Cho, S., Jeon, S., Cho, W. (2009). An investigation of the excavation damaged zone at the KAERI underground research tunnel. Tunnelling and Underground Space Technology, 24 (1), pp.1-13.

DOI:10.1016/j.tust.2008.01.004

[3] Hefny, A. M., Lo, K.Y. (1999). Analytical solutions for stresses and displacements around tunnels driven in crossanisotropic rocks. Int. J. Num. Anal. Meth. Geomech., 23, pp. 161-177.

DOI: 10.1002/(SICI) 1096-9853(199902)23:2<161::AID-NAG963>3.0.CO;2-B

[4] Fu T.-F., Xu, T., Wasantha, P.L.P, et al. (2020). Time-dependent deformation and fracture evolution around underground excavations. Geomatics, Natural Hazards and Risk, 11 (1): pp. 2615-2633.

DOI: $10.1080 / 19475705.2020 .1856202$

[5] Kaiser, P.K., Yazici, S., Maloney, S. (2001). Mining-induced stress change and consequences of stress path on excavation stability - A case Study. Int. Journal of Rock Mechanics and Mining Sciences, 38(2), pp. 167-180.

DOI: 10.1016/S1365-1609(00)00038-1

[6] Zhang, G.-H., Jiao, Y.-Y., Wang, H. Outstanding issues in excavation of deep and long rock tunnels: a case study (2014). Can. Geotech. J., 51 (9), pp. 984-994. DOI: 10.1139/cgj-2013-0087

[7] Barton, N. (2012). Reducing risk in long deep tunnels by using TBM and Drill-and-Blast methods in the same projectthe hybrid solution. Journal of Rock Mechanics and Geotechnical Engineering, 4 (2), pp. 115-126.

DOI: 10.3724/SP.J.1235.2012.00115.

[8] Tang, Z., Liu, X., Xu, Q., et al. (2018). Stability evaluation of deep-buried TBM construction tunnel based on microseismic monitoring technology. Tunnelling and Underground Space Technology. 81, pp. 512-524.

DOI: $10.1016 /$ j.tust.2018.08.028.

[9] Deng, P., Liu, Q., Ma, H., et al. (2020). Time-dependent crack development processes around underground excavations. Tunnelling and Underground Space Technology, 103, 103518. DOI: 10.1016/j.tust.2020.103518.

[10] Yan, P., Lu, W., Chen, M. et al. (2012). Energy release process of surrounding rocks of deep tunnels with two excavation methods. Journal of Rock Mechanics and Geotechnical Engineering, 4 (2), pp. 160-167.

DOI: 10.3724/SP.J.1235.2012.00160.

[11]Ji, F., Lu, J., Shi, Y., Zhou, C. (2013). Mechanical response of surrounding rock of tunnels constructed with the TBM and drill-blasting method. Nat Hazards, 66, pp. 545-556. DOI: 10.1007/s11069-012-0500-2

[12] Cai, M. (2008). Influence of stress path on tunnel excavation response - Numerical tool selection and modeling strategy. Tunnelling and Underground Space Technology, 23: pp. 618-628. DOI: 10.1016/j.tust.2007.11.005.

[13] Suorineni, F.T., Kaiser, P.K., Henning, J.G. (2008). Safe rapid drifting - Support selection. Tunnelling and Underground Space Technology, 23, pp. 682-699. DOI: 10.1016/j.tust.2008.01.002.

[14] Huang, X., Liu, Q., Shic, K., Pan, Y., Liu, J. (2018). Application and prospect of hard rock TBM for deep roadway construction in coal mines. Tunnelling and Underground Space Technology, 73, pp. 105-126. DOI: $10.1016 / j$. tust.2017.12.010.

[15] Zareifard, M. R. (2020). A new semi-numerical method for elastoplastic analysis of a circular tunnel excavated in a Hoek-Brown strain-softening rock mass considering the blast-induced damaged zone. Computers and Geotechnics, 122, 103476. DOI: 10.1016/j.compgeo.2020.103476

[16] Mazaira, A., and Konicek, P. (2015). Intense rockburst impacts in deep underground construction and their prevention. Canadian Geotechnical Journal, 52, pp. 1426-1439. DOI: 10.1139/cgj-2014-0359

[17] Ma, H., Wang, J., Man, K., et al. (2020). Excavation of underground research laboratory ramp in granite using tunnel boring machine: Feasibility study. Journal of Rock Mechanics and Geotechnical Engineering, 12, pp. 1201-1213. DOI: $10.1016 /$ j.jrmge.2020.09.002.

[18] Bao, H., Zhang, K., Yan, C., et al. (2020). Excavation damaged zone division and time-dependency deformation prediction: A case study of excavated rock mass at Xiaowan Hydropower Station. Engineering Geology, 272, 105668. DOI: 10.1016/j.enggeo.2020.105668.

[19] Liu, B., Zhang, D.-W., Yang, C., et al. (2020). Long-term performance of metro tunnels induced by adjacent large deep excavation and protective measures in Nanjing silty clay. Tunnelling and Underground Space Technology, 95, pp. 103147. DOI: $10.1016 /$ j.tust.2019.103147.

[20] Qiu, S.-L., Feng, X.-T., Xiao, J.-Q., et al. (2014). An Experimental Study on the Pre-Peak Unloading Damage Evolution of Marble. Rock Mech Rock Eng, 47, pp. 401-419. DOI:10.1007/s00603-013-0394-7 
[21] Niu, L., Zhu, W., Cheng, Z., et al. (2017). Numerical simulation on excavation-induced damage of rock under quasistatic unloading and dynamic disturbance. Environ Earth Sci. 76, pp. 614. DOI:10.1007/s12665-017-6955-4

[22] Cai, M., Kaiser, P.K. (2005). Assessment of excavation damaged zone using a micromechanics model. Tunnelling and Underground Space Technology, 20, pp. 301-310. DOI: 10.1016/j.tust.2004.12.002.

[23] Luo, T., Wang, S., Zhang, C., Liu, X. (2017). Parameters deterioration rules of surrounding rock for deep tunnel excavation based on unloading effect. Dyna, 92 (6), pp. 648-654. DOI: 10.6036/8554

[24] Yan, C., Yuan, T., Wang, K. (2014). Unloading Phenomena Characteristics in Brittle Rock Masses by A Large-Scale Excavation in Dam Foundation. The Open Civil Engineering Journal, 8, pp. 177-182.

[25] Wu, Z., Jiang, Y., Liu, Q et al. (2018). Investigation of the excavation damaged zone around deep TBM tunnel using a Voronoi-element based explicit numerical manifold method. International Journal of Rock Mechanics and Mining Sciences, 112, pp. 158-170. DOI: 10.1016/j.ijrmms.2018.10.022.

[26] Tian, M., Han, L., Meng, Q. et al. (2019). In situ investigation of the excavation-loose zone in surrounding rocks from mining complex coal seams. Journal of Applied Geophysics, 168, pp. 90-100. DOI: 10.1016/j.jappgeo.2019.06.008.

[27] Eberhardt, E., Stead, D., Stimpson, B. (1999). Quantifying progressive pre-peak brittle fracture damage in rock during uniaxial compression. International Journal of Rock Mechanics and Mining Sciences, 36, pp. 361-380. DOI: 10.1016/S0148-9062(99)00019-4.

[28] Verma, H.K, Samadhiya, N.K., Singh, M., Goel R.K., Singh, P.K. (2018). Blast induced rock mass damage around tunnels. Tunnelling and Underground Space Technology, 71, pp. 149-158. DOI: 10.1016/j.tust.2017.08.019

[29] Yang, H., Huang, D., Yang X., et al. (2013). Analysis model for the excavation damage zone in surrounding rock mass of circular tunnel. Tunnelling and Underground Space Technology, 35, pp. 78-88. DOI: 10.1016/j.tust.2012.12.006

[30] Yang, H.Q., Zeng, Y.Y., Lan, Y.F., et al. (2014) Analysis of the excavation damaged zone around a tunnel accounting for geostress and unloading. International Journal of Rock Mechanics \& Mining Sciences, 69, 59-66. DOI: 10.1016/j.ijrmms.2014.03.003.

[31] Martino, J.B., Chandler, N.A. (2004). Excavation-induced damage studies at the Underground Research Laboratory. Int. J. of Rock Mechanics \& Mining Sciences, 41, pp. 1413-1426. DOI: 10.1016/j.ijrmms.2004.09.010

[32] Siren, T., Kantia, P., Rinne, M. (2015). Considerations and observations of stress-induced and construction-induced excavation damage zone in crystalline rock. International Journal of Rock Mechanics \& Mining Sciences, 73, pp. 165174. DOI: $10.1016 /$ j.ijrmms.2014.11.001

[33] Yang, J.H, Jiang, Q.H, Zhang, Q.B. et al. (2018). Dynamic stress adjustment and rock damage during blasting excavation in a deep-buried circular tunnel. Tunnelling and Underground Space Technology, 71, pp. 591-604. DOI: $10.1016 /$ j.tust.2017.10.010

[34] Gao, C., Zhou, Z., Li, Z., et al. (2020). Peridynamics simulation of surrounding rock damage characteristics during tunnel excavation. Tunnelling and Underground Space Technology, 97, pp. 103289. DOI: 10.1016/j.tust.2020.103289

[35] Tsang, C.-F., Bernier, F., Davies, C. (2005). Geohydromechanical processes in the Excavation Damaged Zone in crystalline rock, rock salt, and indurated and plastic clays - in the context of radioactive waste disposal. International Journal of Rock Mechanics \& Mining Sciences, 42, pp. 109-125. DOI: 10.1016/j.ijrmms.2004.08.003.

[36] Zareifard, M.R., Fahimifar, A. (2016). Analytical solutions for the stresses and deformations of deep tunnels in an elasticbrittle-plastic rock mass considering the damaged zone. Tunnelling and Underground Space Technology, 58, pp. 186196. DOI: $10.1016 /$ j.tust.2016.05.007

[37] Du, X., Zhang, P., Jin, L., Lu, D. (2019). A multi-scale analysis method for the simulation of tunnel excavation in sandy cobble stratum. Tunnelling and Underground Space Technology, 83, pp. 220-230. DOI: 10.1016/j.tust.2018.09.019.

[38] Perras, M.A., Diederichs, M.S. (2016). Predicting excavation damage zone depths in brittle rocks. Journal of Rock Mechanics and Geotechnical Engineering, 8, 60-74. DOI: 10.1016/j.jrmge.2015.11.004.

[39] Malan, D.F. (1999). Time-dependent Behaviour of Deep Level Tabular Excavations in Hard Rock. Rock Mech. Rock Engng., 32 (2), pp. 123-155. DOI: 10.1007/s006030050028.

[40] Malan, D.F. (2002) Manuel Rocha Medal Recipient Simulating the Time-dependent Behaviour of Excavations in Hard Rock. Rock Mech. Rock Engng, 35(4), pp. 225-254. DOI: 10.1007/s00603-002-0026-0

[41] Barla, G., Debernardi, D., Sterpi, D. (2012). Time-Dependent Modeling of Tunnels in Squeezing Conditions. International Journal of Geomechanics. 12, pp. 697-710. DOI: 10.1061/(ASCE)GM.1943-5622.0000163.

[42] Tao, M., Hong, Z., Peng, K., Sun, P., Cao, M., Du, K. (2019). Evaluation of Excavation-Damaged Zone around Underground Tunnels by Theoretical Calculation and Field Test Methods. Energies, 12(9), pp. 1682. DOI: $10.3390 /$ en12091682

[43] Renaud, V., Balland, C., Verdel, T. (2011). Numerical simulation and development of data inversion in borehole ultrasonic imaging. Journal of Applied Geophysics, 73, pp. 357-367. DOI: 10.1016/j.jappgeo.2011.02.007 
[44] Wang, H., Jiang, Y., Xue, S., et al. (2015). Assessment of excavation damage zone around roadways under dynamic pressure induced inactive mining process. Int. Journal of Rock Mechanics \&Mining Sciences, 77, pp. 265-277.

DOI: $10.1016 / j . i j r m m s .2015 .03 .032$

[45] Satici, O., Topal, T. (2021). Assessment of damage zone thickness and wall convergence for tunnels excavated in strainsoftening rock masses. Tunnelling and Underground Space Technology, 108, 103722. DOI: 10.1016/j.tust.2020.103722

[46] Li, T., Cai, M.F., Cai, M. (2007). A review of mining-induced seismicity in China. International Journal of Rock Mechanics \& Mining Sciences, 44, pp. 1149-1171. DOI: 10.1016/j.ijrmms.2007.06.002.

[47] Yang, J., Lu, W., Chen, M., et al. (2013). Microseism Induced by Transient Release of In Situ Stress During Deep Rock Mass Excavation by Blasting. Rock Mech Rock Eng, 46, pp. 859-875. DOI: 10.1007/s00603-012-0308-0

[48] Xie, H., Li, L., Peng, R., et al. (2009). Energy analysis and criteria for structural failure of rocks. Journal of Rock Mechanics and Geotechnical Engineering. 2009, 1, pp. 11-20. DOI: 10.3724/SP.J.1235.2009.00011.

[49] Fan, Y., Zheng, J., Hu, X., et al. (2020). Study on Energy Release of Surrounding Rock under the Multiple Unloading Disturbance during Tunnel Excavation. Mathematical Problems in Engineering, 6486815.

DOI: https://doi.org/10.1155/2020/6486815

[50] Hoxha, D., Giraud, A., Homand, F. (2005). Modelling long-term behaviour of a natural gypsum rock. Mechanics of Materials, 37, pp. 1223-1241. DOI: 10.1016/j.mechmat.2005.06.002.

[51] Lemaitre, J., Chaboche, J.-L. (1990). Mechanics of Solid Materials. Cambridge University Press, Cambridge.

[52] Brantut, N., Heap, M.J., Meredith, P.G., Baud, P. (2013). Time-dependent cracking and brittle creep in crustal rocks: A review. Journal of Structural Geology, 52, pp. 17-43. DOI: 10.1016/j.jsg.2013.03.007.

[53] Tang, S., Yu, C., Tang, C. (2018). Numerical modeling of the time-dependent development of the damage zone around a tunnel under high humidity conditions. Tunnelling and Underground Space Technology, 76, pp. 48-63. DOI: 10.1016/j.tust.2018.03.012.

[54] Yang, S.-Q., Hu, B., Ranjith, P. G., et al. (2018). Multi-Step Loading Creep Behavior of Red Sandstone after Thermal Treatments and a Creep Damage Model. Energies, 11(1), 212. DOI: 10.3390/en11010212

[55] Mu, W., Li, L., Chen, D., et al. (2020). Long-term deformation and control structure of rheological tunnels based on numerical simulation and on-site monitoring. Engineering Failure Analysis, 118, pp. 104928.

DOI: $10.1016 /$ j.engfailanal.2020.104928.

[56] Tang, C., Tang, S. (2011). Applications of rock failure process analysis (RFPA) method. Journal of Rock Mechanics and Geotechnical Engineering, 3 (4), pp. 352-372. DOI: 10.3724/SP.J.1235.2011.00352.

[57] Jiang, Q., Cui, J., Chen, J. (2012). Time-Dependent Damage Investigation of Rock Mass in an In Situ Experimental Tunnel. Materials, 5 (8), pp. 1389-1403. DOI: 10.3390/ma5081389

[58] Zhu, W.C, Liu, J., Tang, C.A., et al. (2005). Simulation of progressive fracturing processes around underground excavations under biaxial compression. Tunnelling and Underground Space Technology, 20, pp. 231-247. DOI: $10.1016 /$ j.tust.2004.08.008

[59] Sun, J.-S., Zhu, Q.-H., Lu, W.-B. (2007). Numerical Simulation of Rock Burst in Circular Tunnels under Unloading Conditions. J. China Univ Mining \& Technology, 17 (4), pp. 0552-0556.

[60] Dong, X., Karrech, A., Basarir, H., et al. (2019). Energy Dissipation and Storage in Underground Mining Operations. Rock Mechanics and Rock Engineering, 52, pp. 229-245. DOI: 10.1007/s00603-018-1534-x

[61] Nasseri, MHB, Mohanty, B., Young, R.P., (2006). Fracture Toughness Measurements and Acoustic Emission Activity in Brittle Rocks. Pure Appl. Geophys, 163, pp. 917-945. DOI 10.1007/s00024-006-0064-8

[62] Peng, K., Lv, H., Zou, Q., et al. (2020). Evolutionary characteristics of mode-I fracture toughness and fracture energy in granite from different burial depths under high-temperature effect. Engineering Fracture Mechanics, 239, 107306. DOI: $10.1016 /$ j.engfracmech.2020.107306

[63] Kusch, A., Salamina, S., Crivelli, D., Berto. F. (2021). Strain energy density criterion as failure assessment for quasi-static uni-axial tensile load, Frattura ed Integrità Strutturale, 57, pp. 331-349. DOI: 10.3221/IGF-ESIS.57.24

[64] Funatsu, T., Seto, M., Shimada, H., et al. (2004). Combined effects of increasing temperature and confining pressure on the fracture toughness of clay bearing rocks. International Journal of Rock Mechanics \& Mining Sciences, 41, pp. 927938. DOI: $10.1016 /$ j.ijrmms.2004.02.008

[65] Momber, A.W. (2015). Fracture Toughness Effects in Geomaterial Solid Particle Erosion. Rock Mechanics and Rock Engineering, 48, pp. 1573-1588. DOI: 10.1007/s00603-014-0658-x

[66] Yang, J., Li, L., Lian, H. (2019). Experimental Evaluation of the Influences of Water on the Fracture Toughness of Mudstones with Bedding. Advances in Materials Science and Engineering, 5693654. DOI: 10.1155/2019/5693654

[67] Keles, C., Tutluoglu, L. (2011). Investigation of proper specimen geometry for mode I fracture toughness testing with flattened Brazilian disc method. Int J Fract, 169, pp. 61-75. DOI: 10.1007/s10704-011-9584-z 
[68] Zhang, ZX. (2002). An empirical relation between mode I fracture toughness and the tensile strength of rock. International Journal of Rock Mechanics \& Mining Sciences, 39(3), pp. 401-406. DOI: 10.1016/S1365-1609(02)00032-1

[69] Nezhad, MM., Fisher, QJ, Gironacci, E., Rezania, M. (2018). Experimental Study and Numerical Modeling of Fracture Propagation in Shale Rocks During Brazilian Disk Test. Rock Mechanics and Rock Engineering, 51, pp. 1755-1775. DOI: $10.1007 / \mathrm{s} 00603-018-1429-\mathrm{x}$

[70] Ghouli, S., Bahrami, B., Ayatollahi, M.R. et al. (2021). Introduction of a Scaling Factor for Fracture Toughness Measurement of Rocks Using the Semi-circular Bend Test. Rock Mech Rock Eng, May 2021. DOI: $10.1007 / \mathrm{s} 00603-021-02468-1$

[71] Guo, L., Latham, J.P., Xiang, J. (2017). A numerical study of fracture spacing and through-going fracture formation in layered rocks. International Journal of Solids and Structures, 110-111, pp. 44-57. DOI: 10.1016/j.ijsolstr.2017.02.004

[72] Karpuz, C., Bozdag, T. (1996). A Comparison On the Double Cantilever Beam And Short Rod Fracture Toughness Test Results of Ankara Andesite. ISRM International Symposium - EUROCK 96, Turin - Italy, September 1996.

[73] Nejati, M., Bahrami, B., Ayatollahi, M.R., Driesner, T. (2021). On the anisotropy of shear fracture toughness in rocks. Theoretical and Applied Fracture Mechanics, 113, 102946. DOI: 10.1016/j.tafmec.2021.102946

[74] Zhang, S., An, D., Zhang, X., et al. (2021). Research on size effect of fracture toughness of sandstone using the centercracked circular disc samples. Engineering Fracture Mechanics, 251, 107777. DOI: 10.1016/j.engfracmech.2021.107777

[75] Feng, F., Chen, S., Li, D., et al. (2020). Excavation unloading-induced fracturing of hard rock containing different shapes of central holes affected by unloading rates and in situ stresses. Energy Sci Eng., 8, pp. 4-27. DOI: 10.1002/ese3.486.

[76] Yu, L., Fu, A., Yin, Q., et al. (2020). Dynamic fracturing properties of marble after being subjected to multiple impact loadings. Engineering Fracture Mechanics, 230, 106988. DOI: 10.1016/j.engfracmech.2020.106988

[77] Zhu, W.C, Liu, J., Tang, C.A., et al. (2005). Simulation of progressive fracturing processes around underground excavations under biaxial compression. Tunnelling and Underground Space Technology, 20, pp. 231-247. DOI: $10.1016 /$ j.tust.2004.08.008

[78] Sun, J.-S., Zhu, Q.-H., Lu, W.-B. (2007). Numerical Simulation of Rock Burst in Circular Tunnels under Unloading Conditions. J. China Univ Mining \& Technology, 17 (4), pp. 0552-0556.

[79] Xiao, Y.X., Feng, X. T., Li, S.J., et al. (2016). Rock Mass Failure Mechanisms during the Evolution Process of rockburst in tunnels. International Journal of Rock Mechanics \& Mining Sciences, 83, pp. 174-181. DOI: 10.1016/j.ijrmms.2016.01.008

[80] Kaiser, P.K., Cai, M. (2012). Design of rock support system under rockburst condition. Journal of Rock Mechanics and Geotechnical Engineering, 4 (3), pp. 215-227. DOI: 10.3724/SP.J.1235.2012.00215.

[81] Zhang, J., Wang, Y., Sun, Y., et al. (2020). Strength of ensemble learning in multiclass classification of rockburst intensity. Int J Numer Anal Methods Geomech., 44, pp. 1833-1853. DOI: 10.1002/nag.3111

[82] Naji, A.M., Emad, M.Z., Rehman, H., et al. (2019). Geological and geomechanical heterogeneity in deep hydropower tunnels: A rock burst failure case study. Tunnelling and Underground Space Technology, 84, pp. 507-521. DOI: 10.1016/j.tust.2018.11.009.

[83] Wu, S., Wang, G. (2011). Rock mechanical problems and optimization for the long and deep diversion tunnels at Jinping II hydropower station. Journal of Rock Mechanics and Geotechnical Engineering, 3 (4), pp. 314-328. DOI: 10.3724/SP.J.1235.2011.00314.

[84] Zhou, J., Li, X., Mitri, H.S. (2018). Evaluation method of rockburst: State-of-the-art literature review. Tunnelling and Underground Space Technology, 81, pp. 632-659. DOI: 10.1016/j.tust.2018.08.029.

[85] Xie, L.T., Yan, P., Lu, W.B., et al. (2018). Effects of Strain Energy Adjustment: A Case Study of Rock Failure Modes during Deep Tunnel Excavation with Different Methods. KSCE Journal of Civil Engineering, 22(10), pp. 4143-4154. DOI: $10.1007 / \mathrm{s} 12205-018-0424-9$.

[86] Li, P.-X., Feng, X.-T., Feng, G.-L., et al. (2019). Rockburst and microseismic characteristics around lithological interfaces under different excavation directions in deep tunnels. Engineering Geology, 260, 105209. DOI: 10.1016/j.enggeo.2019.105209.

[87] Li, X.-B., Zhou, J., Wang, S.-F., et al. (2017). Review and practice of deep mining for solid mineral resources. Chin. J. Nonferrous Metals, 27 (6), pp. 1236-1262. DOI: 10.19476/j.ysxb.1004.0609.2017.06.021

[88] Cheng, W., Wang, W., Huang, S., Ma, P. (2013). Acoustic emission monitoring of rockbursts during TBM-excavated headrace tunneling at Jinping II hydropower station. Journal of Rock Mechanics and Geotechnical Engineering, 5, pp. 486-494. DOI: 10.1016/j.jrmge.2011.09.001.

[89] Xue, Y., Bai, C., Kong, F., Qiu, D., Li, L., et al. (2020). A two-step comprehensive evaluation model for rockburst prediction based on multiple empirical criteria. Engineering Geology, 268, 105515. 
DOI: $10.1016 /$ j.enggeo.2020.105515.

[90] He, S., Lai, J., Zhong, Y., et al. (2021). Damage behaviors, prediction methods and prevention methods of rockburst in 13 deep traffic tunnels in China. Engineering Failure Analysis, 121, 105178. DOI: 10.1016/j.engfailanal.2020.105178.

[91] Pu, Y., Apel, D.B., Lingga, B. (2018). Rockburst prediction in kimberlite using decision tree with incomplete data. Journal of Sustainable Mining, 17, pp. 158-165. DOI: 10.1016/j.jsm.2018.07.004.

[92] Ma, T.-H., Tang, C.A., Tang, S.B., et al. (2018). Rockburst mechanism and prediction based on microseismic monitoring. International Journal of Rock Mechanics and Mining Sciences, 110, pp. 177-188. DOI: 10.1016/j.ijrmms.2018.07.016.

[93] Liu, F., Ma, T., Tang, C.A., et al. (2018). Prediction of rockburst in tunnels at the Jinping II hydropower station using microseismic monitoring technique. Tunnelling and Underground Space Technology, 81, pp. 480-493. DOI: $10.1016 /$ j.tust.2018.08.010.

[94] Manouchehrian, A., Cai, M. (2018). Numerical modeling of rockburst near fault zones in deep tunnels. Tunnelling and Underground Space Technology, 80, pp. 164-180. DOI: 10.1016/j.tust.2018.06.015.

[95] Wang, J.A., Park, H.D. (2001). Comprehensive prediction of rockburst based on analysis of strain energy in rocks. Tunnelling and Underground Space Technology, 16 (1), pp. 49-57. DOI: 10.1016/S0886-7798(01)00030-X.

[96] Zhang, W., Feng, X.-T., Xiao, Y.-X., et al. (2020).A rockburst intensity criterion based on the Geological Strength Index, experiences learned from a deep tunnel. Bulletin of Engineering Geology and the Environment, 79, pp. 3585-3603. DOI: $10.1007 /$ s10064-020-01774-2.

[97] Fan, Y., Lu, W., Zhou, Y., et al. (2016). Influence of tunneling methods on the strainburst characteristics during the excavation of deep rock masses. Engineering Geology, 201, pp. 85-95. DOI: 10.1016/j.enggeo.2015.12.015.

[98] Yan, P., Zhao, Z., Lu, W., et al. (2015). Mitigation of rock burst events by blasting techniques during deep-tunnel excavation. Engineering Geology, 188, 126-136. DOI: 10.1016/j.enggeo.2015.01.011

[99] Shang, Y., Xue, J., Wang, S., et al. (2004). A case history of Tunnel Boring Machine jamming in an inter-layer shear zone at the Yellow River Diversion Project in China. Engineering Geology, 71, pp. 199-211. DOI: 10.1016/S0013-7952(03)00134-0

[100] Yagiz, S., Karahan, H. (2015). Application of various optimization techniques and comparison of their performances for predicting TBM penetration rate in rock mass. International Journal of Rock Mechanics and Mining Sciences, 80, 308-315. DOI: 10.1016/j.ijrmms.2015.09.019

[101] Xu, Z.H., Wang, W.Y., Lin, P., et al. (2021). Hard-rock TBM jamming subject to adverse geological conditions: Influencing factor, hazard mode and a case study of Gaoligongshan Tunnel. Tunnelling and Underground Space Technology, 108, 103683. DOI: 10.1016/j.tust.2020.103683.

[102] Hoek, E. (2001). Big tunnels in bad rock. Journal of Geotechnical and Geoenvironmental engineering. 127 (9), pp. $726-740$

[103] Liu, X.-X., Shen, S.-L., Xu, Y.-S., et al. (2018). Analytical approach for time-dependent groundwater inflow into shield tunnel face in confined aquifer. Int. J. Numer. Anal. Methods Geomech., 42, 655-673. DOI: 10.1002/nag.2760.

[104] Hwang, J.-H., Lu, C.-C. (2007). A semi-analytical method for analyzing the tunnel water inflow. Tunnelling and Underground Space Technology, 22, pp. 39-46. DOI: 10.1016/j.tust.2006.03.003.

[105] Font-Capó, J., Suñé, E.V., Carrera, J., et al. (2011). Groundwater inflow prediction in urban tunneling with a tunnel boring machine (TBM). Engineering Geology, 121, pp. 46-54. DOI: 10.1016/j.enggeo.2011.04.012.

[106] Zhang, C., Liu, N., Chu, W. (2016). Key technologies and risk management of deep tunnel construction at Jinping II hydropower station. Journal of Rock Mechanics and Geotechnical Engineering, 8, PP. 499-512.

DOI: $10.1016 /$ j.jrmge.2015.10.010.

[107] Zhou, X.-P., Huang, X.-C., Berto, F., (2018). An innovative micromechanics-based three-dimensional long-term strength criterion for fracture assessment of rock materials, Frattura ed Integrità Strutturale, 44, 64-81.

DOI: $10.3221 /$ IGF-ESIS.44.06

[108] Tang, S.B., Yu, C.Y., Heap, M.J., Chen, P.Z., Ren, Y.G. (2018). The Influence of Water Saturation on the Shortand Long-Term Mechanical Behavior of Red Sandstone. Rock Mechanics and Rock Engineering, 51, pp. $2669-2687$. DOI: https://doi.org/10.1007/s00603-018-1492-3

[109] JOkubo, S., Fukui, K., Hashiba, K. (2010). Long-term creep of water-saturated tuff under uniaxial compression. International Journal of Rock Mechanics Mining Sciences, 47, pp. 839-844. DOI: 10.1016/j.ijrmms.2010.03.012.

[110] Xiong, L., Li, T., Yang, L. (2014). Biaxial Compression Creep Test on Green-schist Considering the Effects of Water Content and Anisotropy. KSCE Journal of Civil Engineering, 18(1), pp. 103-112.

DOI 10.1007/s12205-014-0276-x

[111] Liu, Y., Liu, C., Kang, Y., et al. (2015). Experimental research on creep properties of limestone under fluid-solid coupling. Environ Earth Sci, 73, pp. 7011-7018. DOI: 10.1007/s12665-015-4022-6 
[112] Lu, Y., Wang, L. (2017). Effect of water and temperature on short-term and creep mechanical behaviors of coal measures mudstone. Environ Earth Sci, 76, 597. DOI 10.1007/s12665-017-6941-x

[113] Hashiba, K., Fukui, K., Kataoka, M., Chu, S.Y. (2018). Effect of water on the strength and creep lifetime of andesite. International Journal of Rock Mechanics and Mining Sciences 108, pp. 37-42. DOI: 10.1016/j.ijrmms.2018.05.006

[114] Li, Z., Liu, S., Ren, W., et al. (2020). Multiscale Laboratory Study and Numerical Analysis of Water-Weakening Effect on Shale. Advances in Materials Science and Engineering, 5263431. DOI: 10.1155/2020/5263431

[115] Cai, X., Zhou, Z., Liu, K., et al. (2019). Water-Weakening Effects on the Mechanical Behavior of Different Rock Types: Phenomena and Mechanisms. Applied Sciences, 9, 4450. DOI: 10.3390/app9204450

[116] Paraskevopouloua, C., Diederichs, M. (2018). Analysis of time-dependent deformation in tunnels using the Convergence-Confinement Method. Tunnelling and Underground Space Technology, 71, 62-80. DOI: $10.1016 /$ j.tust.2017.07.001.

[117] Kontogianni, V., Papantonopoulos, C., Stiros, S. (2008). Delayed failure at the Messochora tunnel, Greece. Tunnelling and Underground Space Technology, 23, pp. 232-240. DOI: 10.1016/j.tust.2007.04.005.

[118] Chen, S.-H. (2015). Hydraulic Structures, Springer-Verlag Berlin Heidelberg. DOI 10.1007/978-3-662-47331-3_13

[119] Sulem, J., Panet, M., Guenot, A. (1987). Closure analysis in deep tunnels. International Journal of Rock mechanics and Mining Science, 24 (3), pp. 145-154. DOI: 10.1016/0148-9062(87)90522-5

[120] Pellet, F., Sahli, M., Boidy, E., et al. (2000). Modelling of time-dependent behavior of Sandstones for deep underground openings. International Symposium on Civil Engineering in the 21 th century, pp. 431-438.

[121] Wang, J.-X., Lin, M.-Y., Tian, D.-X., Zhao, C.-L. (2009). Deformation characteristics of surrounding rock of broken and soft rock roadway. Mining Science and Technology, 19(2), pp. 205-209. DOI: 10.1016/S1674-5264(09)60039-9

[122] Yu, W., Wang, W., Chen, X., Du, S. (2015). Field investigations of high stress soft surrounding rocks and deformation control. Journal of Rock Mechanics and Geotechnical Engineering, 7 (4), pp. 421-433. DOI: $10.1016 /$ j.jrmge.2015.03.014

[123] Yang, S.-Q., Tao, Y., Xu, P., Chen, M. (2019). Large-scale model experiment and numerical simulation on convergence deformation of tunnel excavating in composite strata. Tunnelling and Underground Space Technology, 94, 103133. DOI: 10.1016/j.tust.2019.103133

[124] Wang, J., Li, E., Chen, L., Wang, J., Tan, Y., et al. (2019). Measurement and analysis of the internal displacement and spatial effect due to tunnel excavation in hard rock. Tunnelling and Underground Space Technology, 84, pp. 151165.

[125] Li, C., Hou, S., Liu, Y., Qin, P., et al. (2020). Analysis on the crown convergence deformation of surrounding rock for double-shield TBM tunnel based on advance borehole monitoring and inversion analysis. Tunnelling and Underground Space Technology, 103, 103513. DOI: 10.1016/j.tust.2020.103513

[126] Farrokh, E., Rostami, J. (2009). Effect of adverse geological condition on TBM operation in Ghomroud tunnel conveyance project. Tunnelling and Underground Space Technology, 24, pp. 436-446. DOI: 10.1016/j.tust.2008.12.006.

[127] Huang, F., Wang, Y., Wen, Y., Lin, Z., Zhu, H. (2019). The Deformation and Failure Analysis of Rock Mass Around Tunnel by Coupling Finite Difference Method and Discrete Element Method. Indian Geotech J., 49(4), pp. 421-436. DOI: $10.1007 / \mathrm{s} 40098-018-0348-9$

[128] Deleruyelle, F., Bui, T.A., Wong, H., Dufour, N., Tran, D.K., Zhang, X.S. (2016) Analytical study of the postclosure behavior of a deep tunnel in a porous creeping rock mass. C. R. Mechanics, 344, pp. 649-660.

DOI: $10.1016 /$ j.crme.2016.05.003

[129] Wang, Y.-T., Zhang, X., Liu, X.-S. (2021). Machine learning approaches to rock fracture mechanics problems: Mode-I fracture toughness determination. Engineering Fracture Mechanics, 253, 107890.

DOI: 10.1016/j.engfracmech.2021.107890. 